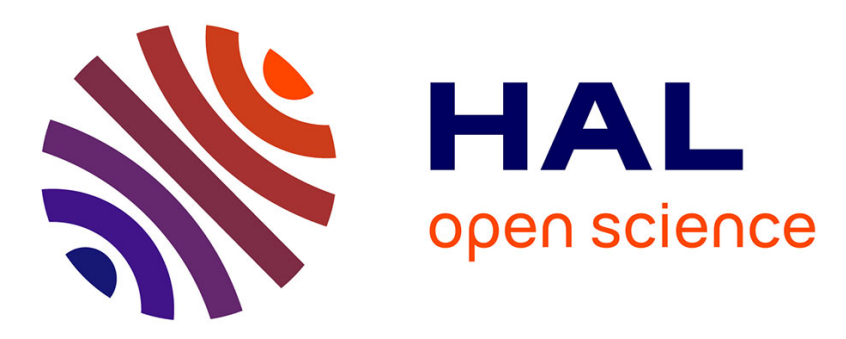

\title{
Nutrition and Feeding Strategy: Impacts on Health Status
}

\author{
Thierry Gidenne, François Lebas, Dominique Licois, Jose I. Garcia
}

\section{To cite this version:}

Thierry Gidenne, François Lebas, Dominique Licois, Jose I. Garcia. Nutrition and Feeding Strategy: Impacts on Health Status. Nutrition of the rabbit, CAB International, 2020, 978-0851992792. hal02569293

\section{HAL Id: hal-02569293 \\ https://hal.inrae.fr/hal-02569293}

Submitted on 11 May 2020

HAL is a multi-disciplinary open access archive for the deposit and dissemination of scientific research documents, whether they are published or not. The documents may come from teaching and research institutions in France or abroad, or from public or private research centers.
L'archive ouverte pluridisciplinaire HAL, est destinée au dépôt et à la diffusion de documents scientifiques de niveau recherche, publiés ou non, émanant des établissements d'enseignement et de recherche français ou étrangers, des laboratoires publics ou privés. 


\title{
10 Nutrition and Feeding Strategy: Impacts on Health Status
}

\author{
T. Gidenne, ${ }^{1}$ F. Lebas, ${ }^{2}$ D. Licois ${ }^{3}$ and J. García ${ }^{4}$ \\ 1 INRA, Occitanie-Toulouse, France; ${ }^{2}$ Cuniculture, Corronsac, France; ${ }^{3}$ St Laurent, \\ France; ${ }^{4}$ Departamento de Producción Agraria, Universidad Politécnica \\ de Madrid, Ciudad Universitaria, Madrid, Spain
}

\subsection{Introduction}

Nutrition and feeding strategies play a key role in rabbit breeding, not only to optimize production itself (e.g. meat, milk, fur), but also to prevent various pathologies through: (i) the presence of toxic compounds in the feeds or utilization of unbalanced diets; and (ii) the presence of pathogenic agents (viruses, bacteria, parasites) in feeds or drinking water. This last aspect is not considered in this chapter since it does not cover nutrition directly but is rather a question of feeding management and hygiene. Similarly, the presence of undesirable pesticides in feed ingredients can impair rabbit health. Very few specific data are available for rabbits in production conditions and so this aspect is also not considered here; readers can consult more specialized books devoted to this aspect of animal feeding.

In this chapter, it is assumed that the daily minimum requirements are covered for the main individual components such as energy, protein and amino acids, minerals and vitamins, as recommended in other chapters. Nevertheless, it is generally difficult to provide all nutrients and energy exactly at the optimum level and, as a consequence of the composition of available raw materials, it is necessary to accept an excess or imbalance in some components to ensure that the minimum of other nutrients is met. By itself, an imbalance should only be responsible for low performance, not for health problems, if the breeding conditions are good. For example, in controlled experimental conditions, a diet containing only $60 \mathrm{~g}$ fibre $\mathrm{kg}^{-1}$ dry matter (DM, as acid detergent fibre, ADF) may not induce digestive trouble (Davidson and Spreadbury, 1975). A similar situation has been observed with diets containing up to 280-300 g crude protein (CP) $\mathrm{kg}^{-1}$ (Lebas, 1973). However, in rabbit-farming conditions, such imbalances lead to a high risk of digestive disorders, and obviously must never be recommended for practical feeding. One of the objectives of this chapter is to indicate the rules to minimize the risk of disorders and give some ideas on 'acceptable' imbalances in feeding practice. In addition to imbalance problems, absolute excess of ingredients such as some minerals (e.g. phosphorus) or vitamins (e.g. vitamin D) can be toxic independently of the health status of rabbits. The only question is - when does a nutrient supplied above the recommended minimum or optimum become toxic?

The present chapter therefore considers health problems (mainly digestive) linked to the balance of dietary components and the presence of nutrients in excess, mainly in relation to the initial composition of feed ingredients, but also to the feeding strategy. We will consider feeding strategies (feed quantity and nutritional quality) for the doe and for the growing rabbit. The last section will cover the health consequences of non-nutritional components that are frequently associated with feed ingredients, such as mycotoxins and water quality. First, we will present 
methods for health status assessment that are practical in rabbit breeding.

\subsection{Health Status Assessment in Relation to Nutrient Intake}

A basic indicator used to evaluate the impact of a disease in breeding is the mortality rate. To obtain a more precise assessment of the health status, morbidity indicators have been developed for the growing rabbit, based on the prevalence of clinical symptoms such as abnormally low growth or diarrhoea (Gidenne, 1995). Morbidity could be added to mortality to calculate the health risk index (HRi)). However, these traits show large variations according to many factors. For instance, the mortality rate of rabbits fed the same diet may range from $0 \%$ up to $70 \%$ according to various factors such as litter effect, preventive medication, age at weaning and the sanitary and immune status of the animals. This means that a large number of animals is required to detect a significant difference in mortality between two treatments. For instance, to detect a difference of $5 \%$ between two mortality rates (e.g. $12 \%$ versus $17 \%$ ), 338 animals are required in each treatment (Table 10.1).

When the clinical symptoms (e.g. diarrhoea, caecal impaction, borborygmus/intestinal rumbling) are clear, the morbidity rate is relatively easy to measure. However, when only a reduction in growth rate is detectable, a threshold must be defined to class the animal as morbid or not: the average $-2 \times$ standard deviation (SD, signifying the $2.5 \%$ of the animals with a lower growth rate) or up to 3 SDs. A large set of rabbits within a group is thus required to calculate the mean and its range of variation. Moreover, adequate statistical methods are necessary to

Table 10.1. Number of rabbits required to detect a significant difference $(P=0.05)$ in the mortality rate between two treatments.

\begin{tabular}{lc}
\hline $\begin{array}{l}\text { Difference to be } \\
\text { detected }(\%)\end{array}$ & $\begin{array}{c}\text { Number of rabbits required } \\
\text { within each treatment }\end{array}$ \\
\hline 5 & 338 \\
10 & 87 \\
15 & 40 \\
20 & 23 \\
\hline
\end{tabular}

treat discrete data (such as mortality or morbidity). To analyse an experimental design with more than one factor or including more than two levels (within a factor) or to test interaction among two factors, a specific categorical analysis based on a weighted least-square analysis must be used instead of a simple chi-squared test.

In addition, studying the effect of a nutrient on digestive health must be conducted without antibiotic treatment; otherwise, the result of mortality will not differ, or will differ only slightly, between treatments. In contrast, a very high mortality ( $>40 \%$ ) from an outbreak (colibacillosis, etc.) invalidates the data, as the disease could crush any effect of the nutrient, and differences between two high mortality rates (Soler et al., 2004) are not directly exploitable for field conditions. Thus, to correlate a nutrient dietary concentration to the mortality or HRi, it is essential to select studies according to these three criteria: sufficient number of rabbits ( $>40$ within a group), no antibiotic treatment and no outbreak that results in very high mortality.

\subsection{Digestive Troubles Related to Nutrient Imbalances}

\subsubsection{Recalls on digestive pathology of the growing rabbit}

Among the various health problems found in conventional rabbit farming, intestinal and respiratory diseases are the two predominant causes of morbidity and mortality. The first mainly occurs in young rabbits, around weaning (4-10 weeks of age), while the second preferentially affects the reproducing female. In France, with batch rabbit-farming systems, post-weaning mortality ranges around 8\% (Lebas, 2018) with the use of metaphylactic anti-biotherapy. However, it may exceed $15 \%$ and even reach up to $50 \%$ in cases of specific epidemic disease (epizootic rabbit enteropathy (ERE) or colibacillosis). Moreover, digestive disorders are responsible for important morbidity often characterized by growth depression and poor feed conversion. These economic losses, more discreet than mortality, are often not identified by rabbit breeders.

Diagnosis of intestinal diseases is difficult because, whatever the cause (nutritional 
problems or a specific pathogen), symptoms and lesions are generally similar. The difficulty in recognizing the aetiology for rabbit intestinal disorders is reinforced by the fact that, as for most diseases in humans or animals, several factors are involved in the development of digestive troubles. The first is the status of the animal itself (age, genetics, immunity). The second concerns the pathogenic agents involved (parasites, bacteria, viruses). The third is represented by environmental factors, including nutritional and feeding factors, breeding conditions such as hygiene, stress and so on. Although many factors are able to provoke a digestive trouble, the most frequent clinical sign is the diarrhoea that occurs in about 0.90 of enteritis cases (Licois, 2004).

The composition of caecal contents as well as caecal function and caecal bacterial community and activity (see Chapter 1) are significantly affected in cases of enteritis (Figs 10.1 and 10.2). The motility of the caecum is stimulated whereas that of the ileum and jejunum is inhibited in experimentally induced diarrhoea with Coccidia (Fioramonti et al., 1981). Furthermore, Hodgson (1974) observed increased motility of the proximal colon, which appeared contracted and thickened, in rabbits fed a low-fibre diet, and a higher retention of digesta in the total tract that should be related to lower feed intake. This probably

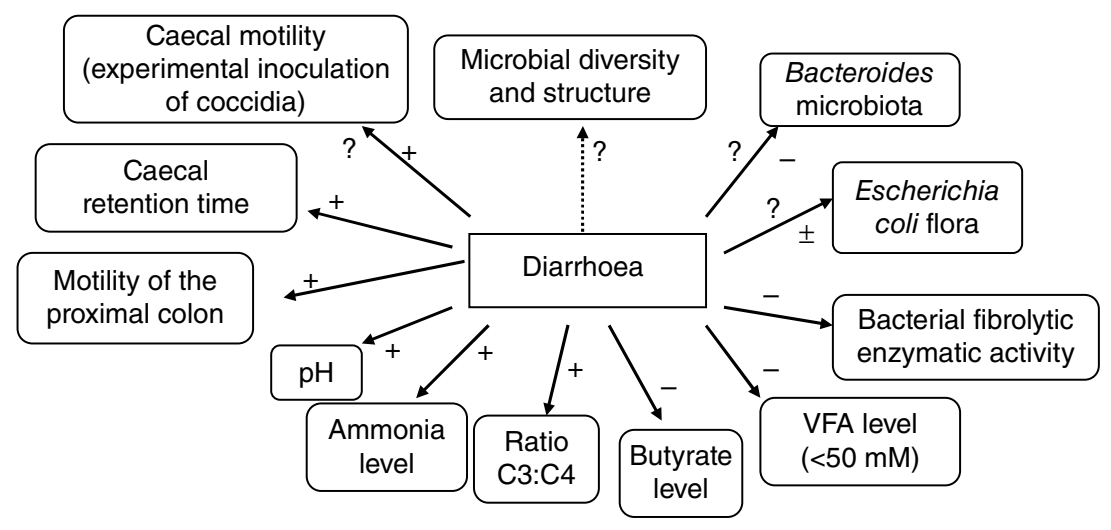

Fig. 10.1. Changes in the caecocolic ecosystem occurring in cases of digestive troubles (diarrhoea) in the growing rabbit (Gidenne, 1997).?, further studies recommended; \pm , inconsistent results; VFA, volatile fatty acid.

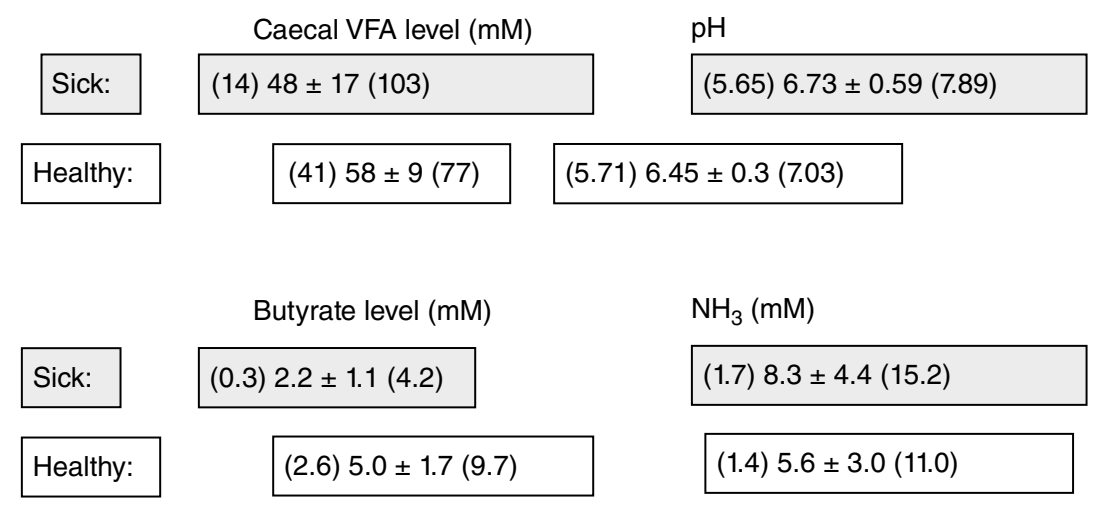

Fig. 10.2. The in vivo caecal fermentation pattern (mean \pm standard deviation) of healthy ${ }^{\mathrm{a}}$ and sick growing rabbits. Figures in parentheses are the minimum and maximum values observed from a set of 80 and 21 rabbits, respectively, for healthy and sick animals (Gidenne, 1997). ${ }^{\mathrm{a} C a e c o-c a n n u l a t e d ~ r a b b i t s, ~}$ $7-11$ weeks old. ${ }^{b}$ Rabbits having acute digestive troubles or abnormally low intake. 
reflects a higher antiperistaltic activity of the proximal colon (see Chapter 1) induced by the high proportion of fine particles in a low-fibre diet. It is thus difficult to postulate that rabbit diarrhoea is characterized by hypomotility of the caeco-colic segment. In parallel, caecal fermentative activity is compromised (Fig. 10.2): for a 6 -week-old rabbit, the caecal volatile fatty acid (VFA) concentration falls to $<50 \mathrm{mM}$, butyrate is particularly affected (leading to a $\mathrm{C} 3: \mathrm{C} 4$ ratio in the range of 1.5-8 instead of 0.5-0.8) and larger inter-individual variations in the fermentation pattern are observed. Higher $\mathrm{pH}(+0.5)$ and ammonia levels are often observed. The composition of the caeco-colic microbiota might also be affected, but the few results available are inconsistent, with some showing a decrease and others an increase in Escherichia coli and/or clostridia.

\subsubsection{Fibre and starch intake for the growing rabbit}

Fibre intake should be expressed in terms of quantity or quality (type) of cell wall constituents (see definition in Chapter 5). Similarly, the effect of starch intake may differ according to the origin of the starch (see definition in Chapter 2).

\section{Fibre intake and hindgut microbial activity and physiopathology}

An increased dietary starch to fibre ratio (associated with $<300 \mathrm{~g}$ neutral detergent fibre (NDF),
$<150 \mathrm{~g} \mathrm{ADF}$ and $>200 \mathrm{~g}$ starch $\mathrm{kg}^{-1}$ ), without major changes in the proportions of the cell wall constituents (e.g. hemicelluloses, lignins), could lead both to a lower ileal flow of DM and bacterial biomass production in the caecum of the young rabbit (Figs 10.1 and 10.2). In healthy growing animals, when the low-digested fibre intake is too low $\left(<8-11 \mathrm{~g} \mathrm{ADF} \mathrm{kg}^{-1}\right.$ live weight day $\left.{ }^{-1}\right)$, the caecal fibre level decreases while the starch concentration remains low (around 15-40 $\mathrm{g} \mathrm{kg}^{-1}$ ) and there are no consistent changes in the concentration of the fermentation end products (ammonia, VFA) and caecal pH (Fig. 10.3). Some authors have described lower fermentative activity (Bellier and Gidenne, 1996; Gidenne et al., 2000, 2002), but most have not. However, the VFA molar proportion is affected by the fibre level, since the proportion of butyrate generally rises significantly when the fibre to starch ratio decreases.

A reduction in ADF dietary level leads to (i) a decrease in fibrolytic activity and (ii) a change in the composition of the microbiota but not its diversity (Combes et al., 2013). The quantities of the major bacterial divisions studied decrease. All these microbial and environmental changes are observable from the second day after the change of diet and remain stable throughout the new dietary period. Moreover, the caecal archaeal community is also affected by a dietary fibre deficiency: it doubles with a standard diet compared to a fibre-deficient diet (Bennegadi et al., 2003). Therefore, the caecal bacterial community of the growing rabbit is able to

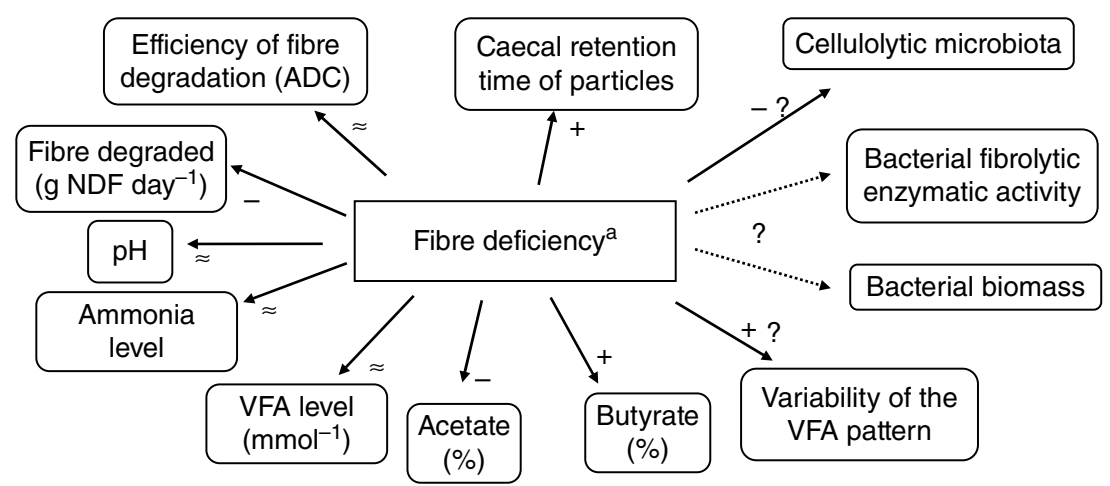

Fig. 10.3. Effect of fibre deficiency ${ }^{\mathrm{a}}$ on several parameters of the caecal ecosystem in the growing healthy rabbit. aLower than $11 \mathrm{~g}$ acid detergent fibre (ADF) $\mathrm{kg}^{-1}$ live weight day ${ }^{-1}$, compared with the required $>15 \mathrm{~g}$ ADF kg ${ }^{-1}$ day $^{-1}$. ?, Further studies needed; $\approx$, not a significant effect. ADC, apparent digestibility coefficient. 
change and adapt rapidly to reach a new equilibrium in response to a nutritional disturbance (e.g. fibre deficiency).

It remains difficult to explain clearly how these changes in the caecal ecosystem determine the greater incidence of digestive troubles (mainly diarrhoea, but also caecal impaction, mucus excretion and low feed intake) observed with low-fibre diets. The favourable effect of a high fibre intake on rabbit digestive health has been shown using an experimental infection model reproducing colibacillosis (Gidenne and Licois, 2005) or ERE (Gidenne et al., 2001b).

Several hypotheses have been proposed to explain how the dietary supply of starch and fibre affects digestive physiology, but none has been completely validated by experimental results. Prohaszka (1980) put forward the antibacterial effect of caecal VFA originating from fibre fermentation, particularly in the case of in vitro E. coli assays. However, numerous studies have not observed a close relationship between the concentration of caecal VFA and $\mathrm{pH}$ or between E. coli flora and caecal pH.

The favourable effect of a high level of low-digestible fibre (lignocellulose or ADF) on digestive health would correspond to a stimulation of the gut motility, particularly in the caecocolic segment. Moreover, most results indicate that factors contributing to a long retention time (low fibre level, reducing the dietary particle size) contribute to modify the caecal microbial balance and activity, and may favour digestive troubles. It could be speculated that a too low caecal turnover rate of digesta leads to an insufficient supply of substrates available for the fibrolytic flora (Fig. 10.4).

\section{Fibre to starch ratio in the feed: relevance for nutritional recommendation of the growing rabbit}

The weaning period is critical because it is associated with a higher prevalence of digestive problems, in relation to a sharp increase in solid feed intake leading to an active maturation of the digestive processes, as for other domestic mammals (piglet, calf, etc., Montagne et al., 2003). The respective effects of fibres and starch on the incidence of diarrhoea in the growing rabbit have been subjected to many studies (Fig. 10.5) comparing the fibre:starch ratio, as in complete feed formulation one dietary component is substituted by another. Consequently, when a study reported a positive effect of increased dietary fibre intake on digestive health, it was in fact difficult to exclude the effect of a reduced starch intake. This issue was addressed by studying the ileal flow of starch and fibres in the growing rabbit (5-9 weeks old). With high-starch diets ( $\geq 300 \mathrm{~g}$ starch $\mathrm{kg}^{-1}$, mainly from wheat), ileal starch digestibility was very high $(>0.97)$; the flow of starch remained $<2 \mathrm{~g} \mathrm{day}^{-1}$ (intake around $30 \mathrm{~g} \mathrm{day}^{-1}$ ) at the ileum, while that of fibre was at least ten times higher (around $20 \mathrm{~g} \mathrm{NDF} \mathrm{day}^{-1}$ ) (Gidenne et al., 2000). Thus, an overload of

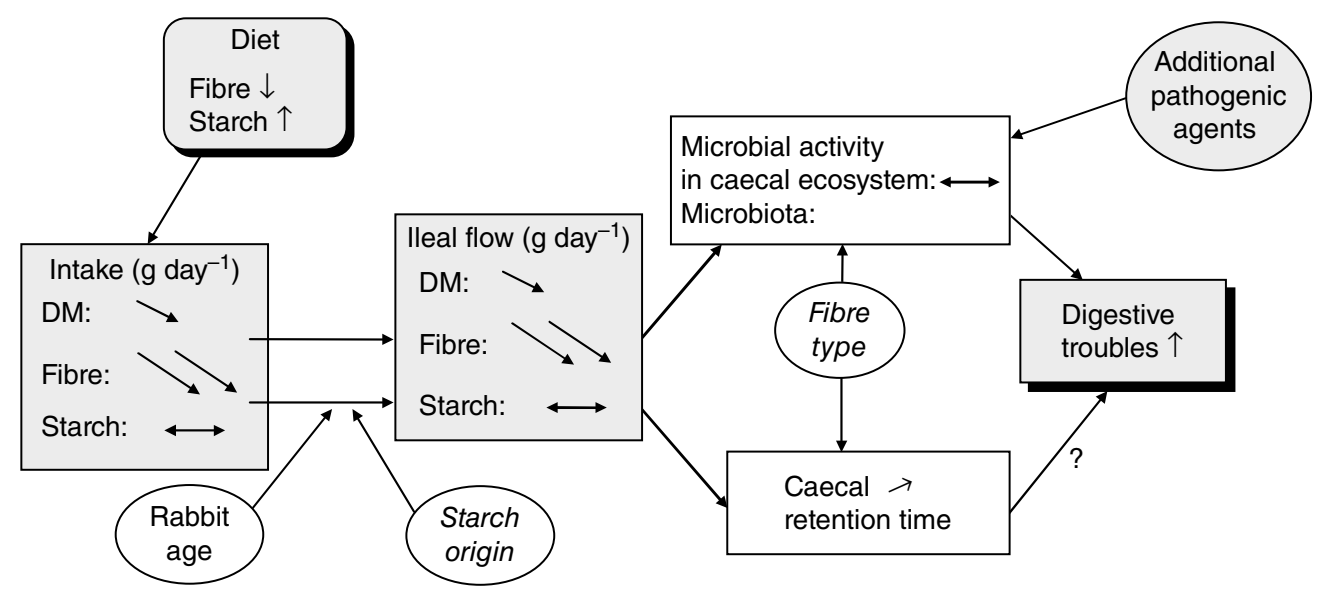

Fig. 10.4. Explanatory diagram to relate low fibre intake and the prevalence of digestive problems in the growing rabbit.?, further studies needed. 


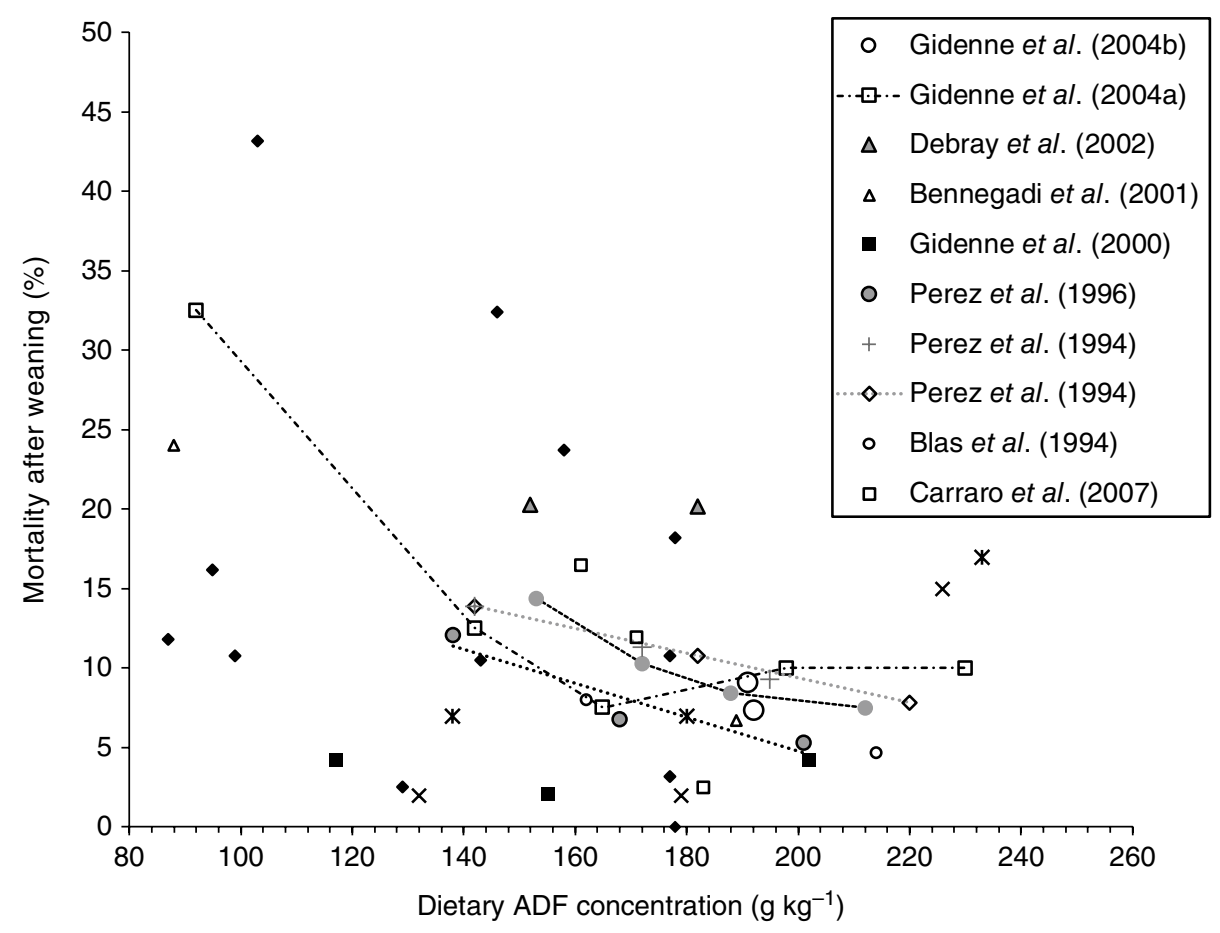

Fig. 10.5. The rabbit post-weaning mortality decreases when the dietary lignocellulose (ADF) concentration increases, but with a highly variable impact within the classical dietary ADF range (150-220 $\left.\mathrm{g} \mathrm{kg}^{-1}\right)$. Data from 12 studies and 46 diets, without antibiotics and varying in their ADF concentration.

starch appears very unlikely, as starch digestibility is over 0.95 already at 5 weeks of age (Blas and Gidenne, 2010). Moreover, a large-scale study using a French network of six experimental breeding units (Groupe Experimentation $\mathrm{Cu}-$ nicole (GEC) group) demonstrated that only the fibre level played a role in digestive trouble and not the starch level (Gidenne et al., 2004b). Furthermore, by comparing iso-fibre diets with several starch sources (maize, wheat, barley) varying in their intestinal digestion, Gidenne et al. (2005a,b) observed no effect of starch ileal flow on the incidence of diarrhoea in the weaned rabbit. These results support the minor influence of starch on the health status of the animal when fibre requirements are covered, and fibre intake thus plays a major role in determining digestive trouble in the classically weaned rabbit (28-35 days old).

Thus in France, the GEC group has performed several large-scale studies to validate clearly the relationships between dietary fibre fractions and digestive health for the 'classically' weaned rabbit using an experimental design with a high number of animals per treatment (over 300 animals per treatment and four to six experimental sites). The relevance of the Van Soest criteria was studied, as the crude fibre criterion was too imprecise for this purpose.

\section{Digestive health and the quantity and quality of lignocellulose}

The beneficial effect of dietary lignocellulose (ADF) ingestion on the frequency of digestive disorders and mortality in fattening rabbits was first shown by Maître et al. (1990) using a largescale experimental design (380 rabbits per diet, in five sites): from 150 to $210 \mathrm{~g} \mathrm{ADF} \mathrm{kg}^{-1}$ the mortality decreased linearly from $14 \%$ to $7 \%$ (Fig. 10.5). The impact of ADF on mortality reduction after weaning was then confirmed by Perez et al. (1994) with a similar design. The relationship between low-fibre diets $(<140 \mathrm{~g} \mathrm{ADF}$ $\mathrm{kg}^{-1}$ ) and a higher incidence of diarrhoea was also clearly established in two studies where the 
quality of fibre, e.g. the proportions of fibre fractions as analysed through the Van Soest procedure, was controlled (Blas et al., 1994; Bennegadi et al., 2001). A meta-analysis (Fig. 10.5) showed that the rabbit post-weaning mortality globally decreases when the dietary lignocellulose (ADF) concentration increases, but with a highly variable impact within the classical dietary ADF range (150-220 $\mathrm{g} \mathrm{kg}^{-1}$ ). Thus, a single criterion such as dietary lignocellulose (or crude fibre) is not sufficient to relate the fibre to the 'level of security' of a feed for the growing rabbit.

A first step is to determine if, apart from the quantity of lignocellulose, the quality of the ADF (the respective effects of lignins and cellulose according to the Van Soest procedure) could have an impact on digestive health. Increasing the intake of lignins (criterion acid detergent lignin (ADL)) involves a sharp reduction of the feed digestibility, associated with a reduction of the digesta retention time in the whole tract $(-20 \%)$, and with a deterioration in the feed conversion ratio (FCR) (Gidenne, 2015). In parallel, a linear negative relationship $\left(R^{2}=\right.$
$0.99, n=5$ feeds) between ADL and mortality by diarrhoea was outlined for the first time by Perez et al. (1994) and confirmed by later studies (Nicodemus et al., 1999; Gidenne et al., 2001a). Increasing the intake of cellulose (ADF - ADL) also reduces the post-weaning mortality rate (Perez et al., 1996) and has less important impact than ADL regarding the decrease of the digestibility or that of retention time (Gidenne and Perez, 1996). Moreover, an increase of the ratio lignins:cellulose is associated with a lower HRi (Gidenne et al., 2001a). However, to date, no adequate and quick analytical method for lignin is available. Consequently, estimating the amount of lignin in a raw material remains difficult, particularly in tannin-rich ingredients such as grape marc, and caution must be taken to establish lignin requirements. The favourable relationship between the dietary ADL level and the HRi was then confirmed with other experiments, as shown in Fig. 10.6, where 0.77 of the variation in the HRi is explained by the variation in dietary ADL. Globally, to reduce the risk of post-weaning digestive disorders,

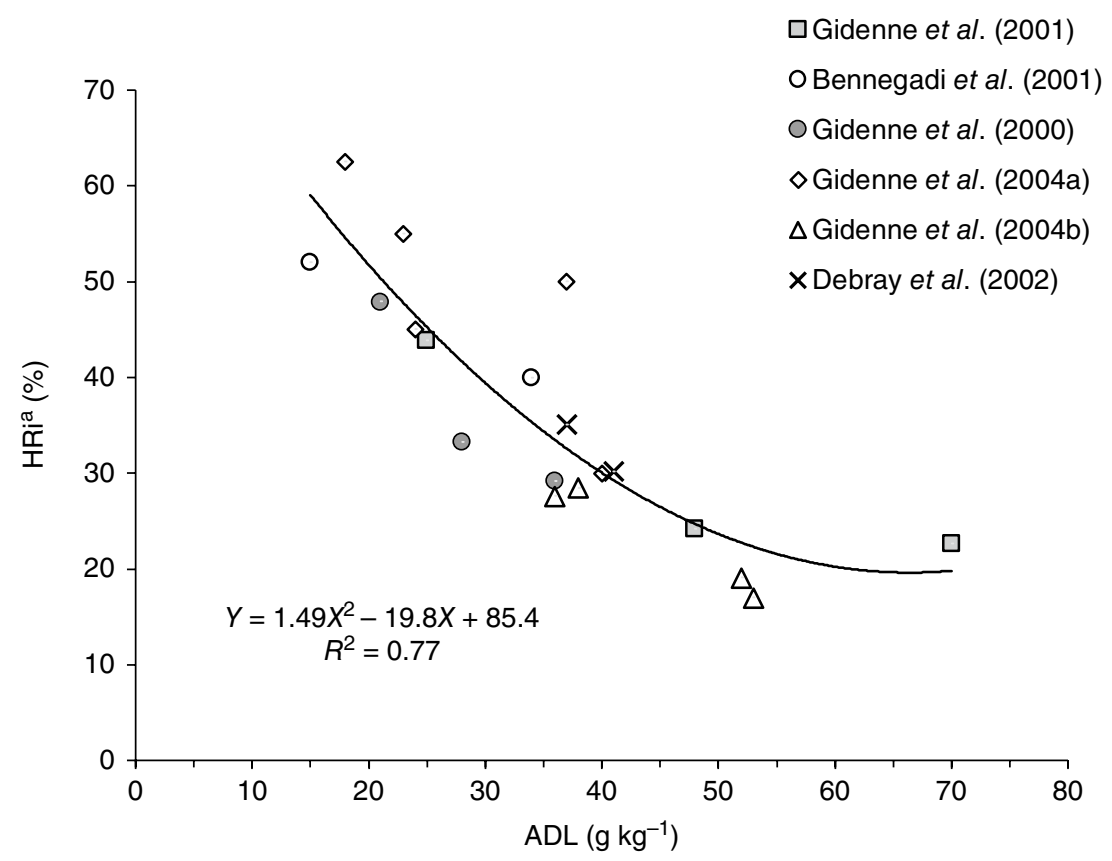

Fig. 10.6. Increasing the dietary lignin level reduced the incidence of post-weaning digestive problems in the growing rabbit. ADL, acid detergent lignin (Van-Soest sequential procedure; EGRAN, 2001). ${ }^{a} \mathrm{HRi}$, health risk index = mortality + morbidity rate by diarrhoea, measured from 28 to 70 days of age, on at least 40 rabbits per diet (data from six studies and 19 diets varying in their ADL concentration). 
the lignin intake (ADL) for the growing rabbit can be assumed to be 5-7 $\mathrm{g}_{\text {day }^{-1}}$ and that of cellulose from approximately $11-12 \mathrm{~g} \mathrm{day}^{-1}$.

\section{Fibre fractions more digested than lignocellulose also impact digestive health}

Hemicelluloses (aNDFom - ADFom), waterinsoluble pectins or soluble fibres (SF: total dietary fibre (TDF) minus NDF) are better digested than cellulose or even lignin (Table 5.4 in Chapter 5). Did these fractions modulate the digestive health of the young rabbit? A first approach is to estimate the fibre fractions that are relatively digestible and in a relatively high content in feeds to reduce the analytical error and to improve the prediction of HRi. Therefore, Gidenne proposed in 2003 a new 'combined' fibre criterion called 'digestible fibres' (DgF), which corresponded to the sum of two fractions: hemicelluloses (analytical value $=\mathrm{NDF}-\mathrm{ADF}$, according to the sequential procedure of Van Soest) and water-insoluble pectins (WIP, analysed or estimated, see Table 10.2). Since the analysis of water-insoluble pectins is complex and not practical in a routine feed laboratory, it is frequently necessary to estimate the WIP value of raw materials from literature (Bach Knudsen, 1997) or from tables of ingredients (Maertens et al., 2002). Some WIP values are given for main fibre sources in Table 5.2.

The DgF fraction plays a key role for digestive health and efficiency, since it is rapidly fermented (compared with ADF) in a delay compatible with the retention time of the caeco-colic segment (9-13h, Gidenne, 1997). The favourable effect of the DgF on digestive health was first demonstrated by Perez et al. (2000) with four iso-ADF diets (Fig. 10.7), in which mortality was reduced by half ( $10 \%$ versus $5 \%$ ) when $\mathrm{DgF}$ replaced starch. More universally, the postweaning mortality rate was globally reduced when digestible fibre (DgF) was added in iso-ADF diets, for four studies out of six without antibiotics (Fig. 10.7), although a large variability remained among the studies. A similar relationship is obtained when we relate the criteria 'TDF ADF' to mortality. If studies using antibiotics are taken into account (solid symbols) the mortality rate differs slightly according to the DgF levels. The relationship between DgF and digestive health is improved by using the HRi criterion (more precise than mortality rate): $R^{2}=0.69$, for five studies measuring HRi (15 diets, Fig. 10.8). The favourable effect of $\mathrm{DgF}$ on digestive health would originate from a stimulated caecal fermentative activity (García et al., 2002) and possibly from the moderate effect on the rate of passage (Gidenne et al., 2004a). Consequently, a too high incorporation of DgF, with respect to lignin and cellulose, should be avoided to minimize the HRi during fattening. It is thus recommended that the ratio DgF:ADF remain under 1.3 for diets having an ADF level over $150 \mathrm{~g} \mathrm{~kg}^{-1}$ (see Table 10.2).

Therefore, a balanced supply of low- and high-digested fibre fractions is required to reduce the risk of digestive trouble for the rabbit after weaning. When a sufficient supply of lignocellulose (at least $180 \mathrm{~g} \mathrm{~kg}^{-1}$ ) is provided, it is advisable to replace some starch by digestible fibre fractions. The HRi is improved whereas the feed efficiency is slightly impaired (Perez et al., 2000; Gidenne et al., 2004b; Tazzoli et al., 2009; Trocino et al., 2011). Furthermore, a substitution of protein by DgF also led to a significant improvement of the digestive health status of the growing rabbit, without significant impairment in growth performance (Xiccato et al., 2011; Gidenne et al., 2013).

\section{Potential roles of quickly fermentable polysaccharides}

These components correspond mainly to watersoluble polysaccharides ( $\beta$-glucans and fructans and some pectins) and oligosaccharides (degree of polymerization > 15) and also to WIP. They are not digested in the small intestine, but rapidly fermented and highly digested in the hindgut. For instance, fructans from chicory roots (an inulin rich ingredient) are almost totally digested and stimulate caecal fermentation (Volek et al., 2011) without change on growth performances. According to Maertens et al. (2004), synthetic fructans would be approximately half-digested before the caecum and they did not find higher caecal VFA level but only a higher butyrate proportion. Addition of inulin in the diet increased the caecal VFA concentration sharply $(+30 \%)$ but failed to reduce significantly the mortality rate (21-77 days old) of the growing rabbits (Volek et al. 2005, 2007). Another way to analyse the role of quickly fermented polysaccharides is to determine the neutral detergent soluble fibre (NDSF) residue (Hall et al., 1997), 


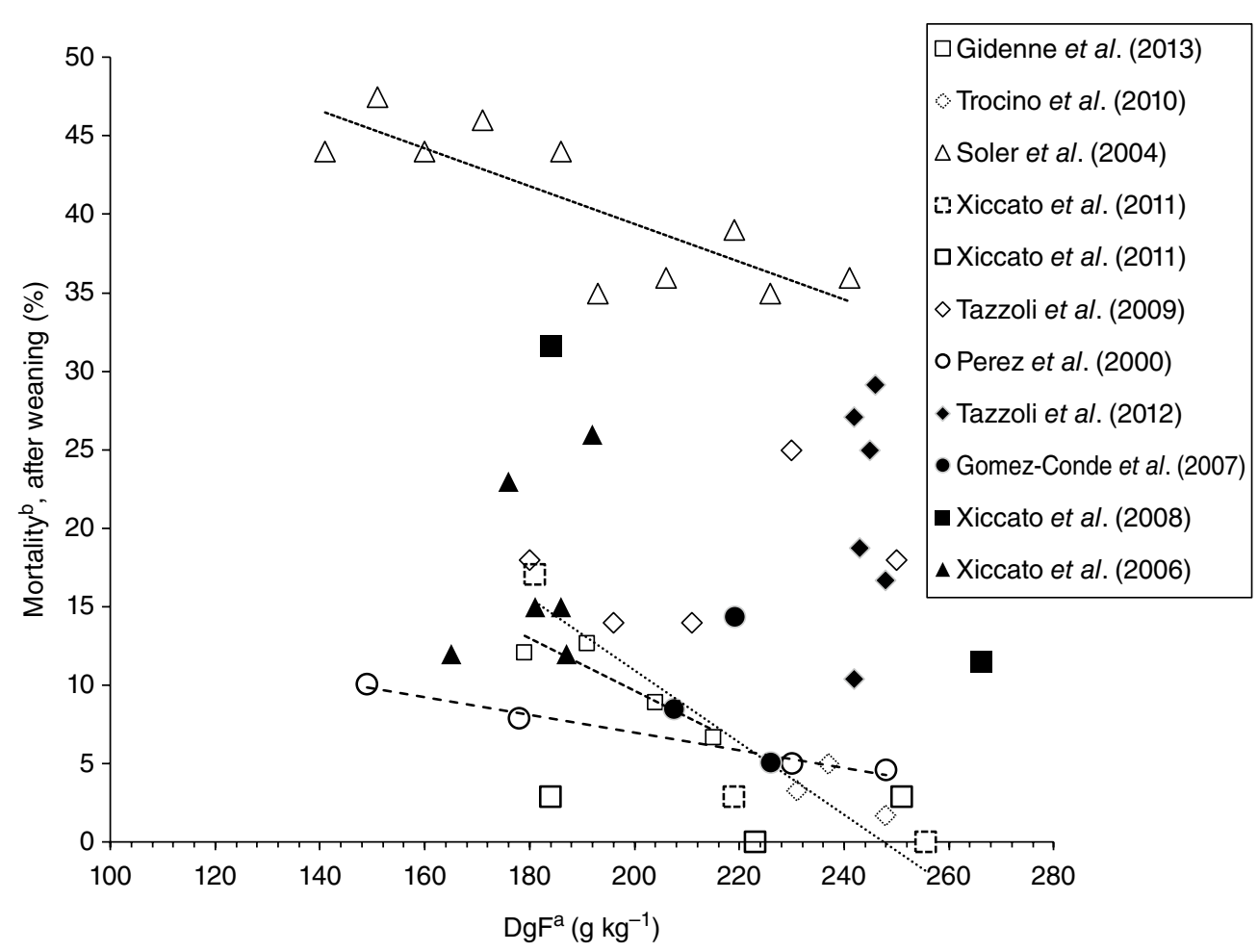

Fig. 10.7. Post-weaning mortality rate of the rabbit is globally reduced when digestible fibres (DgF) are added in iso-ADF diets: without antibiotic or with in-feed antibiotic (solid black symbols). Adding studies using antibiotics (solid black symbols) weakens the relationship.

Data from six studies and 31 diets.

aWithin a study, the DgF level varies, whereas the ADF level slightly varies. ADF = acid detergent fibre according to the Van Soest sequential procedure (EGRAN, 2001); DgF = (NDF - ADF) + WIP. WIP = water-insoluble pectins (see Chapter 5). According to studies, some WIP values were calculated by reformulation from feed ingredients.

${ }^{b}$ Mortality from digestive disorders measured from weaning (28-35 days of age) to slaughter (63-77 days of age), on at least 40 rabbits per diet.

which corresponds to the polysaccharides soluble in the neutral detergent solution. Although the level of NDSF is moderate in rabbit feeds, a reduction of its level (120 versus $80 \mathrm{~g} \mathrm{~kg}^{-1}$ ) could be unfavourable to digestive health of the early-weaned rabbit (Gómez-Conde et al., 2009; Delgado et al., 2018a). Conversely, a higher level of NDSF may improve the mucosal morphology and functionality and its immune response (Gómez-Conde et al., 2007). However, the NDSF criteria remain difficult to analyse, and precision is relatively low for complete feeds with low content of pectins or SF (see also Chapter 5).

Accordingly, another approach is to estimate the content of the quickly fermentable fibre, also called SF, by the difference between the TDF and the aNDFom; the latter must be corrected for its $\mathrm{CP}$ content. SF would be thus easier to handle in a routine laboratory for feed analysis. It would recover the part of TDF that comprises the nonstarch, non-NDF polysaccharides, including pectic substances, $\beta$-glucans, resistant starch, oligosaccharides, fructans and gums. The SF level is generally increased in a complete feed by supplying raw materials rich in pectins (beet pulp, citrus or apple pulp) or fructans (chicory pulp), and thus most of the studies in fact relate 'pulp levels' to performance of physiological data. Accordingly, the SF dietary level is positively related with the faecal digestibility of insoluble fibre fractions (NDF and ADF) and favours the microbial activity with higher fermentation 


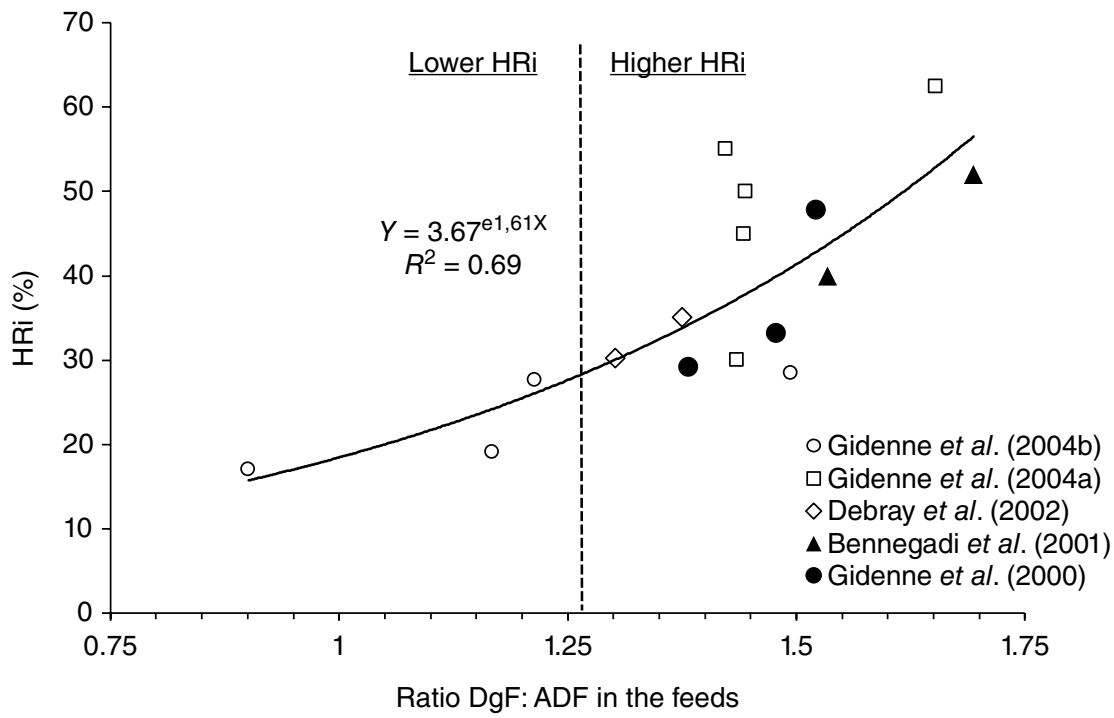

Fig. 10.8. The health risk index $(\mathrm{HRi})^{a}$ in the growing rabbit is jointly dependent of low-digested acid detergent fibre $(A D F)^{b}$ and digestible fibre $(\mathrm{DgF})^{\mathrm{c}}$.

aHRi from digestive problems $=$ mortality + morbidity rate by diarrhoea, measured from 28 to 70 days of age, on at least 40 rabbits per diet (one point $=$ one diet, $n=13$ ).

${ }^{\mathrm{b}}$ ADF: Lignocellulose (Van Soest sequential procedure; EGRAN, 2001).

${ }^{\circ} \mathrm{DgF}$ : sum of water-insoluble pectins + hemicelluloses (NDF - ADF).

Table 10.2. Fibre and starch requirements $\left(\mathrm{g} \mathrm{kg}^{-1}\right)^{\mathrm{a}}$ for the young weaned rabbit to prevent digestive troubles.

\begin{tabular}{|c|c|c|c|c|}
\hline & \multicolumn{2}{|c|}{ INRA } & \multicolumn{2}{|c|}{ Technical University of Madrid } \\
\hline & $\begin{array}{l}\text { Post weaning } \\
\text { (28-42 days old) }\end{array}$ & $\begin{array}{c}\text { Growing } \\
\text { (42-70 days old) }\end{array}$ & $\begin{array}{l}\text { Post weaning } \\
\text { (25-39 days old) }\end{array}$ & $\begin{array}{c}\text { Growing } \\
\text { (39-70 days old) }\end{array}$ \\
\hline $\begin{array}{l}\text { Neutral detergent fibre } \\
\text { (NDF) }\end{array}$ & $\geq 310$ & $\geq 270$ & $300 \leq N D F<350$ & $320 \leq \mathrm{NDF}<350$ \\
\hline Lignocellulose (ADF) & $\geq 190$ & $\geq 170$ & - & $160 \leq \mathrm{ADF}<185$ \\
\hline Lignin (ADL) & $\geq 55$ & $\geq 50$ & - & $\geq 55$ \\
\hline Cellulose (ADF - ADL) & $\geq 130$ & $\geq 110$ & - & - \\
\hline Ratio lignins/cellulose & $>0.40$ & $>0.40$ & - & - \\
\hline $\begin{array}{l}\text { Hemicelluloses } \\
\text { (NDF - ADF) }\end{array}$ & $>120$ & $>100$ & - & - \\
\hline $\mathrm{DgF} / \mathrm{ADF}$ & $\leq 1.3$ & $\leq 1.3$ & - & - \\
\hline $\begin{array}{l}\text { Soluble fibre } \\
\qquad(T D F-N D F)^{c}\end{array}$ & - & - & 120 & - \\
\hline Particles >0.3 mm & - & - & - & $>210^{d}$ \\
\hline Starch & - & - & $<200$ & $145<$ starch $<175$ \\
\hline
\end{tabular}

ADF, acid detergent fibre; ADL, acid detergent lignin; DgF, digestible fibre; NDF, neutral detergent fibre.

${ }^{a}$ As fed basis, corrected to a dry matter content of $900 \mathrm{~g} \mathrm{~kg}^{-1}$.

bHemicelluloses (NDF - ADF) + water-insoluble pectins.

${ }^{\circ}$ Corrected both for ash and protein.

${ }^{\mathrm{d}}$ Fibrous large particles (NDF $>0.3 \mathrm{~mm}$ ) $>160 \mathrm{~g} \mathrm{~kg}^{-1}$.

levels and lower $\mathrm{pH}$, as reviewed by Trocino et al. (2013). As a consequence, the SF level is likely to affect ileal and, especially, caecal microbiota (Gómez-Conde et al., 2007, 2009) by modifying the amount and type of substrate reaching the caecum. These changes in microbiota may also modify the immune response observed in young rabbits fed soluble/insoluble fermentable fibre. 
However, regardless of the advantages and disadvantages of the different methods and calculation procedures, the choice of the method to quantify SF will depend on the correlation with in vivo data collected in animals, and particularly the impact on digestive health.

There is no clear global relationship between the SF, analysed as TDF - NDF, and the post-weaning mortality $\left(R^{2}=-0.04\right)$, although a tendency to a reduction in mortality might be observed (Gidenne, 2015). Even using the same set of studies used in Fig. 10.8, no significant relationship was observed between mortality and dietary SF (Fig. 10.9). This lack of relationship seems logical since SF did not include the hemicellulose fractions that are in large amounts in rabbit feeds. Thus, it remains very risky to recommend an SF concentration in rabbit feeds in order to reduce the risk of digestive troubles. Nevertheless, it seems that above an SF level of $70 \mathrm{~g} \mathrm{~kg}^{-1}$ the mortality rate decreases, but in fact this level is generally reached in feeds that follow the current recommendations for ADF and DgF (Table 10.2). Moreover, criteria for quickly fermentable fibre correspond to a lower amount of fibre residue than for $\mathrm{DgF}$ criteria and, due to a higher analytical error, this could add further imprecision in recommendations. Further studies would be needed to elucidate the health response of rabbits to the SF intake, with large-scale studies comparing the health of large groups of rabbits (over 100). The main problem is to obtain an analytical method sufficiently robust (Xiccato et al., 2012) that it could be used routinely in feed control laboratories.

\section{Effect of the physico-chemical characteristics of the dietary fibre}

Other physicochemical properties such as particle size or cation-exchange or hydration capacity of fibre might influence the digestive physiopathology of the growing rabbit. The particle size distribution of a feed can affect digesta motility, particularly in the caeco-colic segments. Fibrous raw materials with a small proportion of large particles $(>0.3 \mathrm{~mm})$, for example due to a fine grinding (screen size $0.5-1 \mathrm{~mm}$ ), are retained for longer (Laplace and Lebas, 1977; Gidenne et al., 1991; García et al., 1999), but are not associated with a negative effect on the digestive health status (Lebas et al., 1986; Gidenne et al., 1991; Nicodemus et al., 2006). Only a very low content of large particles $(<0.21$ particles of $>0.3 \mathrm{~mm})$ would have a negative impact on performance. Too high a level of dietary coarse particles

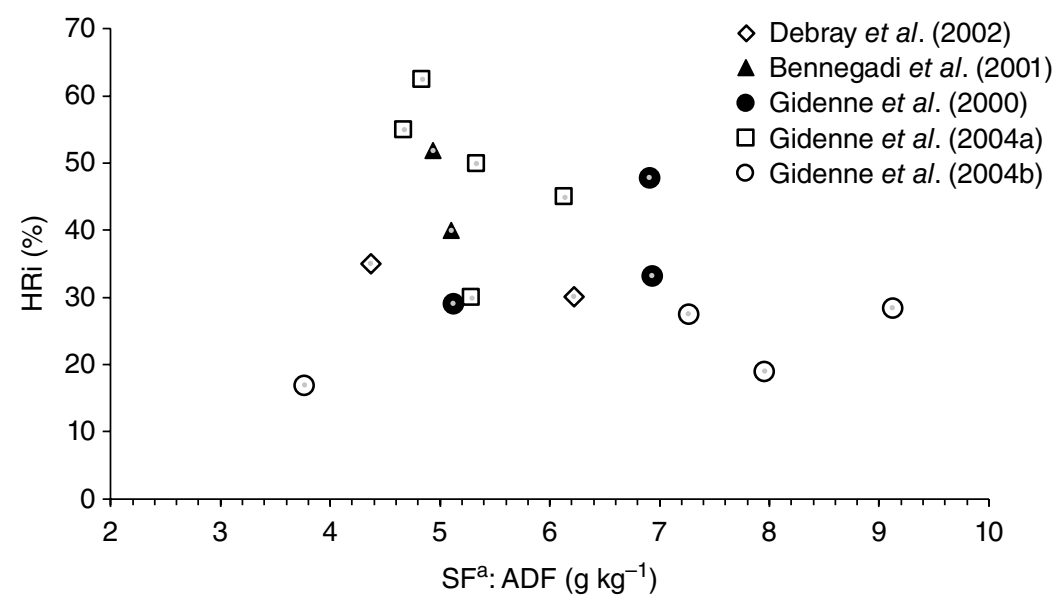

Fig. 10.9. The post-weaning health risk index (HRi) of the growing rabbits is not related to the ratio SF:ADF.

Data from five studies and 16 diets (see Fig. 10.8), without antibiotics, varying in their ratio SF:ADF (within a study, dietary ADF is varying).

$\mathrm{HRi}=$ mortality + morbidity rate by diarrhoea, measured from weaning (28-35 days) to slaughter (63-70 days), on at least 40 rabbits per diet.

aSF is defined as TDF - aNDFom corrected for crude protein; according to studies, values were analysed or calculated by reformulation from feed ingredients. 
$(>0.315 \mathrm{~mm})$ from fibre sources would affect the performance of does and litters (Nicoemus et al., 2010), particularly when low-fibre diets are used to optimize rabbit doe performance.

Nevertheless, a proportion of coarse particles $<0.25$ is unusual in practice; in a series of 77 commercial French feeds, the average proportion of coarse particles was 0.39 (minimum 0.23, mean -2, sDs 0.27; Lebas and Lamboley, 1999).

Cation-exchange or hydration capacity of fibre could modify the digesta viscosity and might influence fibre digestibility, but they do not seem to affect performance or health (García et al., 2000; Volek et al., 2005).

\section{Dietary fibre for the doe and litters}

The favourable effect of dietary fibre has also been analysed in the young rabbit during the weaning period (3-5 weeks old) in a large-scale study (six sites and three reproductive cycles) by Fortun-Lamothe et al. (2005). A lower mortality rate was reported for litters fed on a diet rich in fibre or when fibre and lipid replaced starch. However, in the suckling rabbit (or $<5$ weeks old) it can be speculated that feed intake regulation is not completely established, and neither is pancreatic enzymatic activity (see Chapter 1). The combination of these two factors would lead to a high flow of starch into the caecum (Gidenne et al., 2005a), which may then favour digestive disturbances.

The substitution of starch for fibre has also been studied for doe diets using five iso-energetic diets (10.6 MJ digestible energy (DE) $\mathrm{kg}^{-1}$ ) with increasing levels of NDF (from 278 to $371 \mathrm{~g} \mathrm{~kg}^{-1}$ ) and fat (from 20 to $51 \mathrm{~g} \mathrm{~kg}^{-1}$ ) at the expense of starch (decreasing from 237 to $117 \mathrm{~g} \mathrm{~kg}^{-1}$ ) (de Blas et al., 1995). Some impairment in the performances of does was observed in those fed the highest levels of fibre. This might be explained by higher fermentation losses in the caecum, together with an insufficient uptake of glucose from the gut to meet the requirements for pregnancy and milk lactose synthesis. Conversely, negative effects of high dietary starch concentrations were also mentioned and were related to an increase in diarrhoea mortality for the does. Recently, the combination of SF with essential omega (n-6) fat reduced the number of does removed (culled + mortality) along the first four parturitions (Delgado et al., 2018b), in part related to the increase of the TDF digestibility.

\section{Dietary fibre recommendations to reduce the risk of digestive disorders in the weaned rabbit}

We here propose a summary of the fibre requirement (Table 10.2) for post-weaned and growing rabbits, from French (INRA) and Spanish (Technical University of Madrid) research groups. As described in Chapter 5, to reduce the risk of digestive troubles after weaning, for conventional rabbit breeding systems, one criterion is not sufficient for fibre recommendations.

Three key points must be taken into account. The first criterion to be controlled is the level of ADF, which should be over $190 \mathrm{~g} \mathrm{~kg}^{-1}$ in a complete pelleted feed (Table 10.2). Second, the quality of the lignocelluloses also plays a role in the digestive health, and the minimum level of lignins should be $50 \mathrm{~g} \mathrm{~kg}^{-1}$. Third, the balance between the low-digested ADF and high-digested fibre fraction should be respected: the ratio DgF:ADF should be under 1.3, to avoid an unbalanced intake of highly fermentable polysaccharides (pectins, beta-glucans, etc.). Recent data about the role of SF revealed contradictory results (inadequate number of animals, use of antibiotics) and appears at present not sufficiently consistent to deserve a supplementary recommendation.

In summary, the fibre requirements of the young rabbit before weaning should also be studied, since the nutritional preparation before weaning is probably a key step determining the digestive health of the growing rabbit. Our knowledge of the digestive maturation, including the microbiota implantation in the young rabbit needs to be improved, to provide new concepts for the nutrition of the young in relation to dietary fibres.

\subsubsection{Protein level and quality}

Protein requirements are high in the young animal (see Chapters 12 and 3), not only for body growth but also for intestinal mucosa development and renewal. The ratio of protein to DE in the diet would affect the mortality rate during the fattening period (de Blas et al., 1981). A level of 1.8-1.9 $\mathrm{g} \mathrm{CP} \mathrm{MJ}^{-1} \mathrm{DE}$ seems optimum; even with an increase of up to $2.6 \mathrm{~g}$, Kjaer and Jensen (1997) observed only a slight non-significant increase in mortality. Similarly, Catala and Bonnafous 
(1979) showed that a higher ileal flow of protein (obtained through reduced protein digestion by a ligature of the pancreatic duct) leads to increased microbial proliferation in the hindgut. An excessive protein supply does not affect growth itself, but would favour the proliferation of clostridia and slightly increase the prevalence of E. coli (Haffar et al., 1988; Cortez et al., 1992), and thus could promote digestive problems. For instance, in a large-scale study, Gidenne et al. (2001b) showed that the replacement of protein by digestible fibre significantly reduced the HRi for diarrhoea. It is assumed that a higher supply of proteic substrates for the caecal microbiota will increase the prevalence of pathogenic species. Accordingly, reducing the protein content (210 versus $180 \mathrm{~g} \mathrm{~kg}^{-1}$, Chamorro et al., 2007) would reduce mortality and affect the ileal and/ or caecal bacterial community. The reduction of dietary $\mathrm{CP}$ content led to a reduction in the frequency of detection of Clostridium species (Chamorro et al., 2007). The importance of the reduction of the ileal flow of protein (by using digestible sources or reduced protein level) in reducing the mortality rate was supported by two other studies (García-Ruiz et al., 2006; Chamorro et al., 2007). Glutamine supplementation reduced mortality and affected the ileal and/or caecal bacterial community, reducing the frequency of detection of Clostridium species and Helicobacter species and diminished the presence of Eimeria species in the jejunum (Chamorro et al., 2010; Delgado et al., 2019). Endogenous nitrogen (e.g. digestive enzymes, mucoproteins, desquamated cells, urea) is another relevant source of protein for caecal microbiota, and in rabbits it may represent about 0.64 of the total ileal protein flow (Carabano et al., 2009). In addition, the presence of tannins and other phenolic compounds in the diet would increase the nitrogen flow towards the caecum. Conversely, tannins could protect the intestinal mucosa against oxidative damage and pathogens, and inhibit microbial activity in caecum (García et al., 2002). Maertens and Štruklec (2006) reported a reduction of mortality (under ERE disease) in rabbits fed on diets supplemented with hydrolysable tannins. Finally, the relevance of the nitrogen supply for microbial growth (pathogen or saprophyte) and its consequences on mortality need further research.

Weaning implies a change from milk to vegetable proteins. The digestion of the latter is worse and raw materials occasionally contain antinutritive factors such lectins, antitrypsin or antigenic compounds. This may impair intestinal digestion or induce changes in the morphology of the intestinal mucosa. Scheele and Bolder (1987) observed an increase in mortality before weaning ( 35 days old) in rabbits fed diets containing a high level of soybean meal $\left(200 \mathrm{~g} \mathrm{~kg}^{-1}\right)$ in comparison with two diets based on animal protein (310 versus $100 \mathrm{~g} \mathrm{~kg}^{-1}$, respectively). When animal plasma replaced soybean meal, this improved the morphology of intestinal mucosa, feed intake, growth and reduced mortality (Gutiérrez et al., 2000). Similarly, rabbits fed diets with plant proteins but low in antinutritive factors showed a higher ileal protein digestibility and growth performance and a lower mortality (Gutiérrez et al., 2003).

Most feed manufacturers limit the dietary protein level in fattening diets because of the increased mortality rate when protein levels exceed $20 \mathrm{~g} \mathrm{~kg}^{-1}$. Moreover, an excessive protein supply will probably become increasingly unusual in Europe because of increased dietary cost and, most importantly, because the European animal management strategy favours a reduction in nitrogen excretion to the environment through the use of low-protein diets (Maertens, 1999).

\subsubsection{Lipids}

Few studies have dealt with the role of dietary lipids on the digestive health of growing rabbits, since dietary levels are usually $<30 \mathrm{~g} \mathrm{~kg}^{-1}$ and lipids are well digested in the small intestine. Furthermore, it is difficult to separate the effect of lipids from that of DE intake. However, it has been found that some medium-chain fatty acids (MCFA), such as caprylic and capric acid (in triacylglycerol form), exhibit antimicrobial activity for some bacteria of the caecal digestive microbiota such as E. coli O128 (Skrivanova et al., 2009). Moreover, maternal milk, rich in MCFA, protects the young rabbit against colibacillosis (Gallois et al., 2007) and the addition of MCFA to the feed has a favourable impact on the digestive health of the growing rabbit (Skrivanova and Marounek, 2006). However, contrasting results are obtained when rabbits are experimentally infected with pathogenic E. coli (Gallois et al., 2008; Skrivanova et al., 2008). 
Some fatty acids, such as omega (n)-3, have been implicated in the development of an immune response. Fortun-Lamothe and Boullier (2007) and Maertens et al. (2005) reported a higher post-weaning viability for young rabbits fed a diet with a low omega (n-6) to omega (n-3) ratio (1.0 versus 4.4), while Delgado et al. (2018a) did not detect an effect of the ratio on health status. A moderate addition of fat to starter diets increases the energy intake of kits and contributes to the maintenance of good body condition, and would contribute to digestive maturation and immune system development, thus reducing weaning risk and improving resistance to digestive problems. This assumption must however be confirmed by further studies.

Furthermore, the incorporation of fat in the diets of breeding does may be of interest in terms of increasing their DE intake. However, contradictory results have been obtained indicating either a higher (Lebas and Fortun-Lamothe, 1996) or lower kit mortality (Fraga et al., 1989; Fernandez-Carmona et al., 1996). Despite this, neither the average weight of breeding does nor their fertility or prolificacy were significantly affected by dietary fat incorporation (FortunLamothe, 2006).

\subsection{Feed Intake Limitation and Digestive Pathology of the Growing Rabbit}

Feed intake limitation strategies were studied in the 1970s to analyse the effects on growth, carcass quality or feed efficiency in the growing rabbit. Since 2003, several authors have dealt with the relationship between post-weaning intake level and incidence of digestive problems for the growing rabbit, including studies with experimental infections (either ERE or enteropathogenic E. coli (EPEC)), or large-scale studies in the GEC French network of rabbit experimental units (Gidenne et al., 2012).

Various short-term post-weaning restriction strategies have been studied in the rabbit, in terms of the duration of the restriction period (1-5 weeks), the intensity of the intake limitation (0.90-0.40 of the voluntary intake) or the method (quantitative feed restriction, water restriction, limited time access to the feeder, etc.). Dietary restriction is one of the most effective non-therapeutic ways to reduce the incidence of non-specific enteropathy after weaning (Gidenne et al., 2012). However, the mechanisms of action remain to be elucidated, since neither the morphology of the intestinal mucosa, or maltasic and fibrolytic activity, or caecal VFA levels, or even the structure and diversity of caecal microbiota were affected by a reduction of $25 \%$ in feed intake (Gidenne et al., 2012).

Gidenne et al. (2012) reviewed the effects of a feed restriction on digestive function, health, growth and carcass characteristics, and also on feeding behaviour and welfare, in the growing rabbit challenged by different intake limitation strategies. We will focus here on the main results with respect to the impacts of a transitory feed restriction after weaning on the digestive health of the growing rabbit.

The favourable effect of a quantitative linear reduction of feed intake (ad libitum to 0.6 of ad libitum) on the rabbit digestive health was first shown in 2003, in a multi-centric experiment (six breeding units, 2000 rabbits per treatment; Gidenne et al., 2009a): during feed restriction, the mortality and morbidity rates were sharply reduced (from $12 \%$ to $3.5 \%$ and from $12 \%$ to $6 \%$ for ad libitum +0.9 ad libitum feeding level versus $0.7+0.6$ ad libitum). Moreover, Boisot et al. (2003) also demonstrated a similar positive effect of feed restriction when rabbits were challenged with ERE inoculum. Subsequently, the favourable effect of limiting feed intake on the digestive health of the young rabbit has been confirmed by several studies, as shown by the meta-analysis presented in Fig. 10.10. However, the response of a restriction strategy to mortality after weaning is highly variable according to the breeding system (housing, feeding, weaning age, etc.). The mechanisms underlying the favourable impact of a short-term reduced intake on digestive problems remain unexplained and need further studies. The animal-welfare considerations are contradictory, as feed restriction leads to hunger but reduces the incidence of post-weaning digestive troubles.

Moreover, feed restriction proportionally reduced the growth rate. Thereafter, returning to ad libitum feed intake led to compensatory 


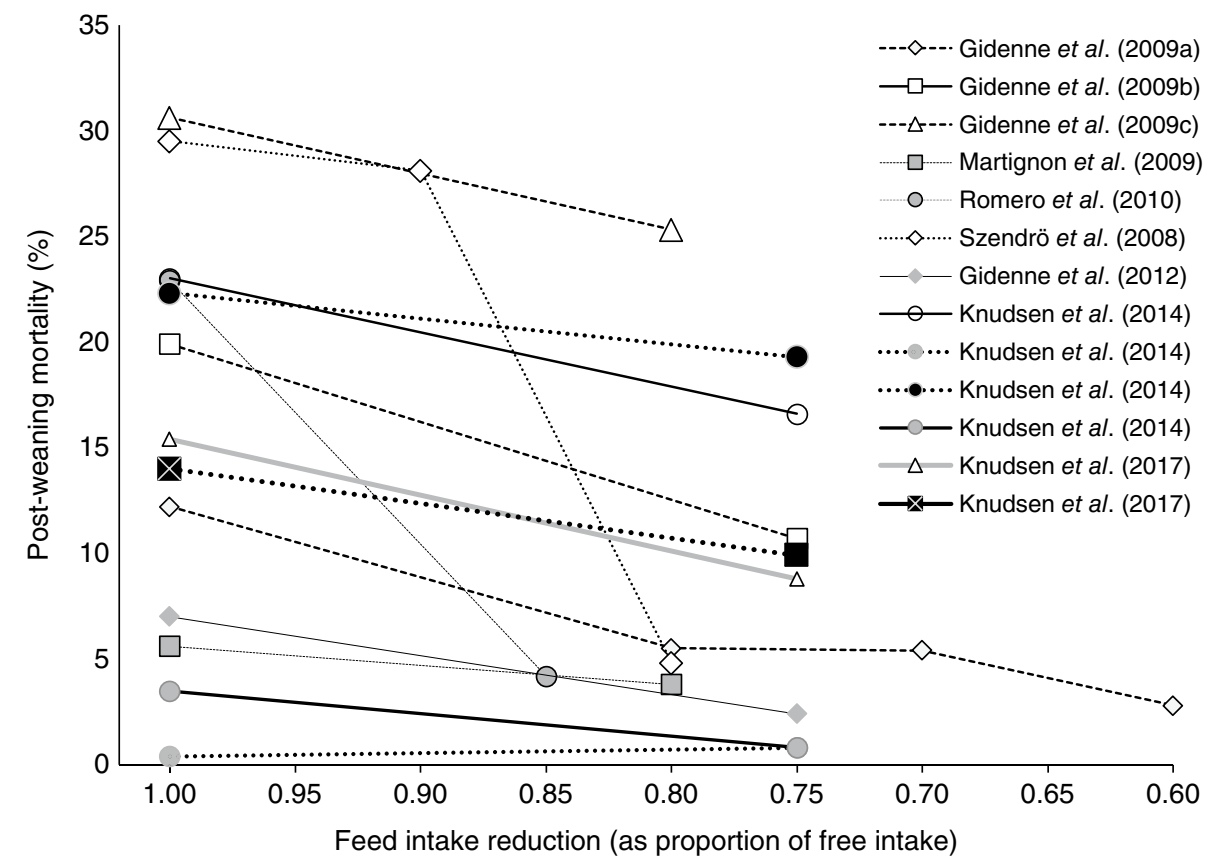

Fig. 10.10. Feed restriction after weaning globally reduces the mortality by digestive disorders after weaning.

Meta-analysis from eight studies and 25 diets, without use of antibiotics.

Post-weaning mortality $=$ mortality rate from weaning to slaughter age (63-70 days), on at least 40 rabbits per diet.

growth and better feed efficiency (Gidenne et al., 2017). Over the whole fattening period, the live weight loss of the more restricted rabbits (0.6 ad libitum) was $7.7 \%$, compared to the control rabbits fed ad libitum from weaning.

Consequently, strategies for controlling the intake of the young after weaning are now widespread in French professional breeders, in parallel with the development of automatic feeding equipment.

Apart from the advantages for digestive health (particularly for ERE syndrome), French breeders use a restriction strategy to reduce feed costs, as the FCR for healthy animals is improved during and particularly after a restriction period because of the compensatory growth. Globally, the margin on the feed cost is estimated at $0.30 €$ (euros) per weaned rabbit. Drug consumption (estimated at about 0.10 to $0.15 €$ per rabbit in France) is also reduced. However, improved returns also depend on the price of feeds, on the national market and particularly on the slaughter weight. For instance, for light slaughter weights (as in Spain) the economic value of restriction strategies may be reduced (Romero et al., 2010).

In conclusion, beneficial effects of a feed intake limitation after weaning have been proved in experiments and in field conditions. Postweaning intake limitation strategies are now widely practised by French rabbit breeders (over 0.90 of French professional breeders), in parallel with the development of new automatic feeding equipment, since beneficial effects have been obtained on resistance to digestive troubles and on feed efficiency. To reduce the risk of postweaning digestive troubles, it is usually recommended to limit the intake to under 0.80 of ad libitum level during the 2 weeks after weaning (35 days). However, intake limitation strategies must be adapted to every breeding system, according to the aims of the farmer: improving health status, reducing feed costs or standardizing performances. 


\subsection{Feeding and Health of the Young Female and of the Doe}

\subsubsection{Feeding and reproductive health of the young female}

Like many farmed animals, the breeding rabbit female must be prepared for its future reproductive life, which often begins around 19 weeks of age in conventional farming systems. Optimizing this preparation from weaning (or even birth) is key to the success of the rabbit's reproductive performance and longevity. This is a major issue for the breeder, knowing that the rabbit female encounters most difficulties early in life (first three litters). In order to prepare young females for this, two factors must be taken into consideration: (i) the age at the first breeding or first AI (artificial insemination): in general it is 19 weeks for selected European lines which at this age have a sufficient physiological maturity; and (ii) body condition: being overweight associated with a high fattening state (prior to first mating) should be prevented to avoid fertility problems at first AI (or mating). In practice, these two factors are often integrated into a single recommendation: young females must reach 0.80 of the adult weight (for their genotype) at the time of the first AI (or mating). However, a disadvantage of this practice is that live weight is a bad indicator of the physiological maturity of the female (see also Chapter 6 and Chapter 14).

If the young female is fed freely after weaning with an energy feed that is too high ('maternity' type), 0.80 of the adult weight is reached too quickly with an excessive fattening. The farmer can choose from several techniques to limit energy intake. One method is to control the growth curve to reach a target weight $(0.80$ of adult weight) at a fixed age, varying the dietary energy concentration by applying a "quantitative' feed restriction (lower feed supply) for a limited period (with possible alternation of free intake periods) to reach the target weight at a fixed age at the first AI. The advantages of a quantitative feed restriction between 9 and 11 weeks of age, and between 17 and 19 weeks of age (except for a flushing before AI), are a reduction in the mortality of young females, a reduction in perinatal mortality of the litter at the beginning of their careers, and a more moderate mobilization of body reserves between the first $\mathrm{AI}$ and the birth, and between the first birth and the second AI. However, applying a feed restriction strategy to control the growth of young rabbits can be complicated. In particular, care should be taken to avoid protein, vitamin and mineral ingestion deficiencies during this key period of body development of young females.

Another solution, faced with the problems of an excess of fattening or of difficult restriction strategy, is to use a low energy feed $(<10 \mathrm{MJ}$ $\left.\mathrm{kg}^{-1}\right)$ and rich in fibre $\left(>220 \mathrm{~g} \mathrm{ADF} \mathrm{kg}^{-1}\right)$ to stimulate the ingestion capacity of the growing female. Thus, the daily feed intake of the female is higher and leads to a stronger intake of protein and a better energy balance. The size of the litter at first birth and the weight of the rabbits at weaning would also be improved, but these results are to be confirmed. The most important aspect of using high-fibre feeds is related to the preparation of young females to better utilize their body reserves at the end of gestation and at the end of lactation period which can improve fertility at the second AI (with a breeding cycle of 6 weeks).

Current knowledge needs to be consolidated to identify the best feeding strategy for the future breeding female. More detailed information on the nutritional management of the future breeding female is detailed in the review by Martínez-Paredes et al. (2015).

\subsubsection{Feeding and health of the adult reproducing female}

The prevalence of digestive disorders is lower in the adult female than in growing rabbits. Fibre requirements are usually covered by a feed containing at least $150 \mathrm{~g} \mathrm{ADF}, 350 \mathrm{~g} \mathrm{NDF}, 45 \mathrm{~g}$ lignin $\mathrm{kg}^{-1}$ (see also Chapter 6 and Chapter 14). Critical points mainly concern the energy supply and digestible protein (DP) needs and the protein:energy (DP:DE) ratio.

The breeding female must cover her needs for maintenance (renewal of tissues in neutral thermal conditions), thermoregulation, pregnancy (fetal growth, mammogenesis), lactation, immunity and physical activity. If the female has not completed her growth (age $<6$ months), it is 
also necessary to add growth requirements. These needs are generally considered to be additive: as an example, for a lactating young female (first litter), we must add the requirements (in energy, or protein, or amino acids) for maintenance, growth and lactation. The adult female regulates her intake according to the dietary energy content and the energy intake is proportional to the metabolic weight (MW), around 1100-1300 kJ DE $\mathrm{kg}^{-1} \mathrm{MW}$ for a female in full lactation (2 to 3 weeks after kindling). However, in conventional breeding systems, the energy needs often exceed the intake capacity and the female thus uses her body reserves to meet her needs. Even with high-energy feeds (10.4-11.2 $\mathrm{MJ} \mathrm{DE} \mathrm{kg}^{-1}$ ) the energy balance could be negative at the end of lactation. Along the successive reproductive cycles, the female thus gains and then loses body weight. The main difficulty is having variations in the body weight that are too large and impair the health of the female and of the litter.

The source of the energy in the feed could also impact the health (body condition) of the female. For instance, whereas the female regulates her energy intake according to the energy content of the feed, the lactating female will increase her energy intake with a feed having a higher energy level $\left(>9 \mathrm{MJ} \mathrm{kg}^{-1}\right)$. This effect is more pronounced in multiparous females than in primiparous ones and when the energy supplement is provided with lipids rather than with starch. Conversely, the effects on fertility and prolificacy are much more contradictory. For the same energy concentration, the milk production of females increases when the feed is enriched in fat. The milk is then also richer in lipids, which promotes the growth of young rabbits (live weight at weaning: $+2.1 \% \mathrm{~g}^{-1}$ ether extract) and their survival rate. If the extra energy comes from starch, the milk production of females does not increase, and even decreases in some studies. The composition of the milk is not affected by an increase in the starch content of the feed. Globally, the higher milk production induced by the addition of fat results in greater body mobilization in primiparous females. However, over the long term, increasing the energy content with starch or fat in the feed has a positive effect on the female body condition.
Obviously, the reproductive rhythm strongly influences the energy balance of the female, and thus the health status. For an intensive reproduction rhythm, the female is pregnant during lactation, which increases the requirements (milk + fetal growth). In the long term this situation can become problematic because females do not have (post-partum or 32-day cycle) or have only a few (35- or 42-day cycle) periods with less production, during which they can rebuild body reserves. This results in either an increase in female loss (culled or dead), or periods of infertility during which females restore their body reserves.

The need for DP must also be covered by the feed and, for breeding females, it is recommended to use a feed containing 175-190 g CP and 125$138 \mathrm{~g} \mathrm{DP} \mathrm{kg}^{-1}$, corresponding to a DP:DE ratio of 11.5 to $12.5 \mathrm{~g} \mathrm{DP} / \mathrm{MJ}$ DE. The highest values are recommended for high-producing females in intensive rhythms. A decrease in the DP:DE ratio will reduce milk production and therefore the size and/or weight of the litter rather than the body condition of the female. In contrast, an increase in the dietary protein level (up to $210 \mathrm{~g}$ $\mathrm{kg}^{-1}$ ) can increase milk production but may slightly reduce the number of weaned rabbits.

\subsubsection{Interaction between female feeding and health of young before weaning}

The nutritional requirements of young rabbits before weaning are not completely known due to methodological difficulties (simultaneous milk supply, group rearing, etc.). However, some studies have shown that the distribution of a highfibre feed before weaning promotes the viability of young rabbits after weaning. This also seems true with a supply of rapidly fermentable fibre in the caecum (soluble pectins, $\beta$-glucans, fructans). Unweaned rabbits do not seem to regulate their energy intake as accurately as weaned rabbits and seem to show an appetite for energy-rich feeds. They will therefore have a higher energy intake which will have a positive effect on their weight at weaning but may increase the subsequent digestive problems if the fibre intake (quantity and quality) is not simultaneously maintained at a sufficient level. 
Since females and young rabbits have access to the same feed until weaning, feeding has a direct influence on the growth of young rabbits and an indirect influence by its effects on the composition and especially on the quantity of milk produced by their mother. However, the nutritional needs of the mother and those of young rabbits before weaning are antagonistic. The female has very high energy requirements to ensure both fetal growth and milk production. Conversely, the young rabbit requires high-fibre feeds (low energy) to reduce the risk of digestive disorders around weaning. For this, some of the starch can be replaced with fibre, but the feed will be of lower energy and may not cover all the needs of the female (reproduction and/or lactation). Weaning diet is therefore often a compromise to cover the needs of females and young rabbits.

\subsection{Problems Associated with Dietary Compounds Present at Toxic Levels}

\subsubsection{Minerals and vitamins}

Although recommendations for optimum and maximum levels of mineral and vitamins are described in detail in Chapter 7, it is important for the current chapter to consider maximum acceptable levels in diets. In effect it is important that, during diet formulation, there is control over nutrient levels such that, even if analysis is not available, they are well below toxic levels.

The main available information is summarized in Table 10.3. The values are those from Lebas et al. (1996) amended according to the most recent data obtained mainly during the

Table 10.3. Maximum levels of minerals or vitamins that can be given without problems and levels known to induce signs of toxicity in the rabbit.

\begin{tabular}{|c|c|c|c|}
\hline & $\begin{array}{l}\text { Maximum level } \\
\text { observed without } \\
\text { problems }\end{array}$ & $\begin{array}{l}\text { Concentration } \\
\text { with signs of } \\
\text { toxicity }\end{array}$ & Period of life \\
\hline \multicolumn{4}{|l|}{ Minerals } \\
\hline \multirow{2}{*}{ Calcium $\left(\mathrm{g} \mathrm{kg}^{-1}\right)$} & 25 & 40 & Growth \\
\hline & 19 & 25 & Reproduction \\
\hline \multirow[t]{2}{*}{ Phosphorus $\left(\mathrm{g} \mathrm{kg}^{-1}\right)$} & 8 & - & Growth \\
\hline & 8 & 10 & Reproduction \\
\hline Magnesium $\left(\mathrm{g} \mathrm{kg}^{-1}\right)$ & 3.5 & 4.2 & Growth \\
\hline Sodium $\left(\mathrm{g} \mathrm{kg}^{-1}\right)$ & 6 & 7 & Growth \\
\hline \multirow[t]{2}{*}{ Potassium $\left(\mathrm{g} \mathrm{kg}^{-1}\right)$} & 16 & $15-20$ & Growth \\
\hline & 16 & 20 & Reproduction \\
\hline Chlorine $\left(\mathrm{g} \mathrm{kg}^{-1}\right)$ & 4.2 & - & Growth \\
\hline Copper (ppm) & $150-200$ & $200-300$ & Growth \\
\hline Fluorine (ppm) & - & 400 & Growth \\
\hline \multirow[t]{2}{*}{ lodine (ppm) } & 10,000 & - & Growth \\
\hline & - & 100 & Reproduction \\
\hline Iron (ppm) & 400 & 500 & Growth \\
\hline Manganese (ppm) & - & 50 & Growth \\
\hline Selenium (ppm) & 0.32 & - & Growth \\
\hline Zinc (ppm) & 200 & 400 & Growth \\
\hline \multicolumn{4}{|l|}{ Vitamins } \\
\hline \multirow[t]{2}{*}{ Vitamin A (IU kg-1) } & 100,000 & - & Growth \\
\hline & 40,000 & 75,000 & Reproduction \\
\hline Vitamin D (IU kg-1) & 2,000 & 3,000 & Reproduction \\
\hline \multirow[t]{2}{*}{ Vitamin $\mathrm{E}\left(\mathrm{mg} \mathrm{kg}^{-1}\right)$} & 300 & - & Growth \\
\hline & 160 & - & Reproduction \\
\hline Vitamin $\mathrm{C}\left(\mathrm{g} \mathrm{kg}^{-1}\right)$ & 2 & - & Growth \\
\hline Vitamin $\mathrm{C}\left(\mathrm{mg} \mathrm{kg}^{-1}\right)$ & 400 & - & Reproduction \\
\hline
\end{tabular}


last World Rabbit Congresses: Bernardini et al. (1996) and Virag et al. (2008) for vitamin E in the growing rabbit; Abdel-Khalek et al. (2008) for vitamins $\mathrm{E}$ and $\mathrm{C}$ in breeding does; Abd El-Rahim et al. (1996) for iron; and Guimarães and Motta (2000) and Ayyat and Marai (2000) for zinc.

It must be pointed out that the maximum acceptable level is in general far higher than the recommended level, but with some noticeable exceptions such as potassium, phosphorus and vitamin D.

\subsubsection{Mycotoxins}

Mycotoxins are metabolites produced by certain fungi in the field on standing crops or during the harvesting of feedstuffs. Mould growth can also occur on stored grains or other raw materials because of non-hygienic storage conditions. These toxic substances may be contained within the spore or secreted into the substrate on which the fungi are growing. Most of these substances have a high degree of animal toxicity. Feeding rabbits on naturally-mouldy diets (mixed toxin contamination) is responsible for many problems such as decreased feed intake, functional alteration of the liver and genital tract and changes in blood constituents (Abdelhamid, 1990). Mycotoxicoses appear in chronic and acute forms. The acute form is caused by the rapid ingestion of large amounts of toxins over a short period. For more details, see the review of Mézes and Balogh (2010).

Aflatoxins are naturally occurring toxins produced in grains and other feedstuffs both before and after harvest by toxigenic strains of the fungi Aspergillus flavus and Aspergillus parasiticus. Aflatoxin B1 (AFB1) is of primary concern because it is the most abundant and the most toxic. Acute or chronic aflatoxicoses may occur depending on the dietary concentration of toxins. Rabbits are extremely sensitive to aflatoxin. The acute, oral, single-dose median lethal dose is about $0.3 \mathrm{mg} \mathrm{kg}^{-1}$ body weight (Newberne and Butler, 1969), among the lowest of any animal species. Moderate to severe mortality can be encountered with diets containing even low concentrations of toxin $(<100 \mathrm{ppb})$ (Krishna et al., 1991). Signs of toxicity include hepatic lesions (Abdelhamid et al., 2002), anorexia, weight loss and emaciation, followed by icterus/ jaundice in the terminal stages (Morisse et al., 1981). Acute aflatoxin poisoning (AFB1 daily doses $>0.04 \mathrm{mg} \mathrm{kg}^{-1}$ body weight) causes a prolonged blood-clotting time, extensive liver damage and death from liver failure (Clark et al., 1980, 1982, 1986).

Zearalenone (F-2 toxin) is an oestrogenic substance that is frequently recovered from maize and other grains contaminated by Fusarium graminearum (Perez and Leuillet, 1986). Zearalenone causes hypertrophic development of the genital tract of the female rabbit (Pompa et al., 1986; Abdelhamid et al., 1992). It can also affect components of the uterine tubal fluid known to be of critical importance during the early preimplantation period (Osborn et al., 1988). Zearalenone induces changes in blood serum enzyme activities. Low doses $\left(10 \mu \mathrm{g} \mathrm{kg}^{-1}\right)$ result in significant increases in alkaline phosphatase (ALP) activity, while higher doses $\left(100 \mu \mathrm{g} \mathrm{kg}^{-1}\right)$ lead to significant increases in the activity of aspartate aminotransferase, alanine aminotransferase, ALP, $\gamma$-glutamyl transpeptidase and lactate dehydrogenase, indicating possible liver toxicity due to chronic effects of the toxin (Čonková et al., 2001). Levels of zearalenone in feed as low as 1-2 ppm can interfere with the normal reproductive activity of rabbits when fed for only a few days (1-2 weeks). This high sensitivity of rabbits to this mycotoxin could be related to the slow hepatic transformation of zearalenone mainly into $\alpha$-zearalenol, a more uterotrophic metabolite (Pompa et al., 1986).

Another group of toxins produced by Fusarium species is the trichothecenes: T-2 toxin and vomitoxin. T-2 toxin is produced by some strains of the fungus Fusarium tricinctum. It is relatively common in fibrous raw materials that have been harvested or stored in poor conditions. In affected rabbits, T-2 toxin causes marked feed refusal, lesions of the digestive tract and impairment of blood-clotting mechanisms (Gentry, 1982; Fekete et al., 1989). Long-term (4-7 weeks) feeding of sub-lethal quantities of T-2 toxin (0.19 ppm) have been found to alter the ovarian activity of sexually mature female rabbits (Fekete and Huszenicza, 1993). Administration per os of $4 \mathrm{mg} \mathrm{kg}^{-1}$ body weight of T-2 toxin causes death within $24 \mathrm{~h}$ (Vanyi et al., 1989). 
Vomitoxin (4-deoxynivalenol) may be found in cereal grains. Contamination of rabbit feeds with this toxin results in feed refusal and vomiting. Adverse effects on fetal development have also been encountered in does. Khera et al. (1986) observed that a level of $0.00024 \mathrm{mg}$ vomitoxin $\mathrm{g}^{-1}$ diet caused a $100 \%$ incidence of fetal resorption.

The nephrotoxins (ochratoxin and citrinin) have been also implicated in rabbit mycotoxicoses. Ochratoxin is produced by toxigenic strains of Aspergillus ochraceus. Galtier et al. (1977) examined the excretion of ochratoxin A in rabbit females after a single intravenous administration (1-4 $\mathrm{mg} \mathrm{kg}^{-1}$ body weight) and demonstrated transfer of the toxin into the milk: the level in milk reached $1 \mathrm{ppm}$ for the highest dose of administration. The actual toxicity for rabbits is unknown, but it can be pointed out that, in the above-mentioned experiment, lactating does accommodated a single dose of $4 \mathrm{mg} \mathrm{kg}^{-1}$ body weight.

Citrinin is found in mouldy cereals contaminated by various fungal species of Aspergillus and Penicillium. Ingestion of this toxin induces acute erosive gastritis and fluid diarrhoea, with some rabbits dying less than $24 \mathrm{~h}$ after oral administration of a single $100-130 \mathrm{mg} \mathrm{kg}^{-1}$ body weight dose (Hanika et al., 1983). In the rabbit, citrinin also causes renal damage with tubular dysfunction and necrosis similar to that found in other animal species (Hanika et al., 1984).

\subsection{Water Quality and Pathology}

In most texts on animal nutrition, the part devoted to water quality is very short. A common comment is that 'the water provided for animals must be drinkable' and the recommended values given are those for human consumption, without further comment.

If these values are effectively obtained at the watering point available to the animals, there is effectively no health problem linked to water quality. Nevertheless, the bacterial and chemical composition of the water destined for animal drinking does not always respect all of the recommended criteria.

In no way should water polluted with bacteria be recommended for rabbits, even if it is known that animals are more tolerant than humans. As very simple low-cost systems are available, the solution is disinfection. The classic criteria for the bacterial quality of drinkable water are presented in Table 10.4.

For minerals, removing the excess is technically possible in most cases, but the cost is very high and the constant question is: is it necessary for the health of rabbits? Different experiments have been conducted to establish the real tolerance of rabbits to mineral concentrations in drinking water, mainly in hot sub-Saharan regions or in intensive animal production areas. The results are summarized in Table 10.5. Values are given for each mineral, but it does not mean that water with all of criteria at maximum will be accepted by rabbits.

It can be pointed out that, when known, the tolerance limits of rabbits are very wide compared to the maximum 'officially' acceptable values for human consumption. One of the most significant is the tolerance of rabbits to high levels of nitrates or nitrites (tenfold the maximum accepted for human consumption), which has led to considerable debate in intensive animal production regions such as the Netherlands or Brittany in France. None of the maxima for rabbits is lower than that recommended for human consumption. Therefore, no specific chemical control is necessary if the water provided for rabbits is the same as that provided for human consumption by a controlled public system. Conversely, alteration of water quality by increasing some minerals can be illegal for human consumption, but is not necessarily injurious to rabbit health (Table 10.5).

Table 10.4. Recommended bacteriological status of drinkable water for human consumption. ${ }^{\text {a }}$

\begin{tabular}{ll}
\hline Microorganisms & Maximum count \\
\hline Salmonella spp. & 0 in $5,000 \mathrm{ml}$ \\
Staphylococcus spp. & 0 in $100 \mathrm{ml}$ \\
Enteroviruses & 0 in $10,000 \mathrm{ml}$ \\
Faecal Streptococcus spp. & 0 in $100 \mathrm{ml}$ \\
Thermo-tolerant coliforms & 0 in $100 \mathrm{ml}$ \\
Clostridium spp. & 1 in $20 \mathrm{ml}$ \\
\hline
\end{tabular}

a Official Journal of the European Communities, 1998; Council Directive 98/83/EC of 3 November, 1998, on the quality of water intended for human consumption. 
Table 10.5. Chemical composition of drinkable water for rabbits.

\begin{tabular}{|c|c|c|c|c|}
\hline \multirow[b]{2}{*}{$\begin{array}{l}\text { Physical parameter } \\
\text { (units) }\end{array}$} & \multicolumn{2}{|c|}{$\begin{array}{l}\text { Official recommendations } \\
\text { for human consumption }\end{array}$} & \multicolumn{2}{|c|}{$\begin{array}{l}\text { Maximum experimented on rabbits } \\
\text { without problems }\end{array}$} \\
\hline & $\begin{array}{l}\text { Recommended } \\
\text { maximum }\end{array}$ & $\begin{array}{l}\text { Maximum } \\
\text { tolerable }\end{array}$ & Value & Reference \\
\hline $\mathrm{pH}$ & $7-8.5$ & $6.5-9.2$ & $3.5-9.0$ & Porter et al. (1988) \\
\hline \multicolumn{5}{|l|}{$\begin{array}{l}\text { Chemical parameters } \\
\text { (in ppm) }\end{array}$} \\
\hline Total soluble salts & 500 & 1500 & 3000 & Abel-Samee and El-Masry (1992) \\
\hline Sodium & 100 & 150 & 900 & Ayyat et al. (1991) \\
\hline Potassium & 10 & 12 & 140 & Ayyat et al. (1991) \\
\hline Phosphorus & 2 & 5 & - & \\
\hline Calcium & 75 & 200 & 400 & Porter et al. (1988) \\
\hline Magnesium & 30 & 150 & - & \\
\hline Iron & 0.2 & 1.0 & - & \\
\hline Copper & 0.1 & 1.5 & 60 & Abo El-Ezz et al. (1996) \\
\hline Manganese & 0.05 & 0.5 & 12 & Abel-Samee and El-Masry (1992) \\
\hline Zinc & 5 & 15 & 55 & Abel-Samee and El-Masry (1992) \\
\hline Aluminium & 0.2 & - & 250 & Rémois and Rouillière (1998) \\
\hline Antimony & 0.01 & - & - & \\
\hline Arsenic & 0.05 & 0.20 & - & \\
\hline Cadmium & 0.005 & 0.05 & - & \\
\hline Chromium & 0.05 & 1.0 & - & \\
\hline Cobalt & - & 1.0 & - & \\
\hline Fluoride & 1.5 & 2.0 & - & \\
\hline Lead & 0.05 & 0.10 & 0.40 & Habeeb et al. (1997) \\
\hline Mercury & 0.001 & 0.01 & - & \\
\hline Nickel & 0.05 & 1.00 & - & \\
\hline Selenium & 0.01 & - & - & \\
\hline Silver & 0.01 & - & - & \\
\hline Vanadium & - & 0.10 & - & \\
\hline Chloride (Cl) & 250 & 600 & 1100 & Habeeb et al. (1997) \\
\hline Sulfate $\left(\mathrm{SO}_{4}\right)$ & 200 & 400 & 1340 & Rémois and Rouillière (1998) \\
\hline Nitrate $\left(\mathrm{NO}_{3}\right)$ & 45 & 50 & 600 & Kammerer and Pinault (1998) \\
\hline Nitrite $\left(\mathrm{NO}_{2}\right)$ & 0.05 & 0.10 & 11 & Morisse et al. (1989) \\
\hline Ammonium $\left(\mathrm{NH}_{4}\right)$ & 0.05 & 0.50 & - & \\
\hline $\mathrm{H}_{2} \mathrm{~S}$ & 0.05 & 0.10 & - & \\
\hline Bicarbonate & - & - & 400 & Ayyat et al. (1991) \\
\hline $\begin{array}{l}\text { Nitrogen ( } \mathrm{N} \text { from } \mathrm{NO}_{2} \\
\text { and } \mathrm{NO}_{3} \text { excluded) }\end{array}$ & 2 & - & - & \\
\hline 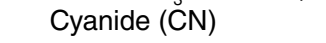 & 0.05 & - & - & \\
\hline
\end{tabular}

a Official Journal of the European Communities, 1998; Council Directive 98/83/EC of 3 November, 1998, on the quality of water intended for human consumption.

\subsection{Additives Potentially Improving the Health Status of the Rabbit}

\subsubsection{Exogenous enzymes and specific amino acid supplementation}

Some positive effects of fibrolytic exogenous enzyme supplementation (a mixture of $\beta$-glucanases, $\beta$-xylanases, $\alpha$-amylases and pectinases) on mortality were found (Gutiérrez et al., 2002b; Cachaldora et al., 2004) and might be related to a partial hydrolysis of non-starch polysaccharides that produce complex oligomers, which may modulate the gut microbiota and lead to better digestive health. However, these results need to be confirmed. Moreover, it has been found that experimentally induced ileal flow of lactose could lead to a higher mortality (Gutiérrez et al., 
2002a) possibly explained by a microbiota imbalance in the caecum.

The dietary addition of proteases could also help to reduce nitrogen flow (Carabano et al., 2009), but mainly in the post-weaning period when animals have a limited enzymatic capacity to hydrolyse protein (Dojana et al., 1998). Accordingly, the results of García-Ruiz et al. (2006) showed that dietary supplementation with proteases was effective in the reduction of nitrogen ileal flow both for sunflower- and soybean-based diets. However, this reduction only improved the intestinal health in animals fed on the sunflower diets. The presence of antinutritive factors or allergenic compounds in soybean-based diets might exert an additional effect on mortality.

Due to the relatively slower daily gains after weaning, the higher weight of gut maintenance on total requirements can significantly increase the relative needs for certain essential and nonessential amino acids with respect to advanced stages of growth. In addition, the defence mechanisms of the intestinal barrier can have specific needs for amino acids. Thus, threonine is a major component of mucin proteins, whereas glutamate is the main amino acid used by enterocytes as an energy source that plays an essential role in the repairing mechanisms of mucosa tissue (Le Floc'h and Séve, 2000; Reeds et al., 2000). Recent studies in rabbits (Baylos et al., 2008; Chamorro et al., 2010) indicate that dietary supplementation with glutamine reduced the mortality caused by ERE, modified ileal microbiota (with a decrease in the frequency of detection of several pathogens such as C. perfringens and Helicobacter species), and diminished the presence of Eimeria species in the jejunum. Therefore, a reduction in the protein level, even when the supply of most limiting amino acids for growth is maintained (lysine, sulfur and threonine), may reduce the supply of other essential or non-essential amino acids that could also affect growth performance or health.

\subsubsection{Other products: prebiotics, probiotics}

\section{Effects of prebiotics}

A prebiotic is defined as a non-digestible feed ingredient that positively affects the host by selectively stimulating the growth and/or activity of one or a limited number of intestinal bacteria. Prebiotics are mostly short-chain carbohydrates (or oligosaccharides) that are not hydrolysed in the small intestine and arrive unchanged in the caecum and colon. Prebiotics are thus a rapidly fermentable substrate and lead to the production of lactic acid and VFA. Fructo-oligosaccharides (FOS) are known to stimulate the growth of Bifidobacteria and Lactobacilli, both of which are considered beneficial bacteria to the host. The manno-oligosaccharides (MOS) used in chicken, veal and pork production would reduce the risk of digestive tract colonization by pathogenic microorganisms by a mechanism of competitive exclusion. Indeed, mannose binds to type 1 fimbriae, which corresponds to a filament that many bacteria use to bind to host cells. In chickens supplemented with MOS, salmonellae bind to mannose, thus reducing the carriage density. In rabbits, studies on the influence of prebiotics concerned mainly growth performance and caecal fermentation activity with contradictory results even for the same type of prebiotic (for review, see Maertens et al., 2006; Falcao-e-Cunha et al., 2007). According to Falcao-e-Cunha et al. (2007), this lack of consensus may be attributed to variation in experimental factors between studies, but also because of the nature of rabbit feed, which is rich in fibre and thus may contain significant amounts of oligosaccharides. Recently, an effect of MOS on the structure of the mucosa was observed with an increase in the size of ileal villi (Mourao et al., 2006), whereas inulin did not appear to affect the counts of anaerobic bacteria and E. coli (Bonai et al., 2010). Recently the cellobiose supplementation in drinking water $\left(7.5 \mathrm{~g} \mathrm{~L}^{-1}\right)$ showed a positive effect on mortality in a farm affected by ERE, probably due to its butyrogenic effect (Ocasio-Vega et al., 2018, 2019). However, a higher dose of cellobiose or its combination with SF exerted the opposite effect, suggesting a strong interaction with the intestinal microbiota.

\section{Effects of probiotics}

Probiotics are living microorganisms used as feed additives for animals and humans that can modulate the activities of the digestive microbiota to improve the health or performance of the host. They consist of one or more species of live microorganisms, with or without culture 
residues. The biological effects of probiotics are generally highly dependent on the microorganism strains used, on their ability to maintain metabolic activity in the digestive environment and on their cellular concentration. In rabbits, according to the literature (see reviews of Maertens et al., 2006; Falcaoe-Cunha et al. 2007), the addition of a probiotic tends to improve growth performance when the breeding conditions are not optimal. Recent results confirmed the favourable effects of live yeast (Saccharomyces cerevisiae; Kimsé et al., 2012) or Bacillus cereus var. toyoii (Bonai et al., 2008; Pascual et al., 2008) on rabbit health. Addition of Bacillus cereus var. toyoii decreased the coliform germ count (Bonai et al., 2008) and tended to decrease Clostridium species (Pascual et al., 2008).

\section{References}

Abdelhamid, A.M. (1990) Effect of feeding rabbits on naturally moulded and mycotoxin-contaminated diet. Archives of Animal Nutrition 40, 55-63.

Abdelhamid, A.M., Kelada, I.P., Ali, M.M. and El-Ayouty, S.A. (1992) Influence of zearalenone on some metabolic physiological and pathological aspects of female rabbits at two different ages. Archives of Animal Nutrition 42, 63-70.

Abdelhamid, A.M., Ragab, M.A. and EI-Shaieb, A.F. (2002) The use of tafla or aluminosilicate for alleviating toxic effects of aflatoxin-contaminated diets of growing rabbits. In: Proceedings of the 1st Conference of Animal and Fish Production. Mansoura, Egypt, pp. 389-413.

Abdel-Khalek, A.M., Selim, N.A., El-Medany, Sh.A. and Nada, S.A. (2008) Response of doe rabbits to dietary antioxidant vitamins $E$ and $C$ during pregnancy and lactation. In: Xiccato, G., Trocino, A. and Lukefahr, S.D. (eds) Proceedings of the 9th World Rabbit Congress, Verona. Fondazione Iniziative Zooprofilattiche e Zootecniche, Brescia, Italy, pp. 519-523.

Abd El-Rahim, M.I., El-Kerdawy Dawlat, A., El-Kerdawy, H.M. and Abdallah Fatma, R. (1996) Bioavailability of iron in growing rabbits fed excess levels of dietary iron, under Egyptian conditions. In: Lebas, F. (ed.) Proceedings of the 6th World Rabbit Congress, Toulouse, Vol. 1. Association Française de Cuniculture, Lempdes, France, pp. 51-57.

Abel-Samee, A.M. and El-Masry, K.A. (1992) Effect of drinking natural saline well water on some productive and reproductive performance of California and New-Zealand White rabbits maintained under north Sinai conditions. Egyptian Journal of Rabbit Science 2, 1-11.

Abo El-Ezz, Z.R., Salem, M.H., Hassan, G.A., El-Komy, A.G. and Abd El-Moula, E. (1996) Effect of different levels of copper sulphate supplementation on some physical traits of rabbits. In: Lebas, F. (ed.) Proceedings of the 6th World Rabbit Congress, Toulouse, Vol. 1. Association Française de Cuniculture, Lempdes, France, pp. 59-65.

Ayyat, M.S. and Marai, I.F.M. (2000) Growth performance and carcass traits as affected by breed and dietary supplementation with different zinc levels, under Egyptian conditions. In: Becerril, C.M. and Pro, A. (eds) Proceedings of the 8th World Rabbit Congress, Puebla. Colegio de Postgraduados, Montecillo, Spain, pp. 83-88.

Ayyat, M.S., Habeeb, A.A. and Bassuny, S.M. (1991) Effects of water salinity on growth performance, carcass traits and some physiological aspects of growing rabbits in summer season. Egyptian Journal of Rabbit Science 1, 21-34.

Bach Knudsen, K.E. (1997) Carbohydrate and lignin contents of plant materials used in animal feeding. Animal Feed Science and Technology 67, 319-338.

Baylos, M., Menoyo, D., Chamorro, S., Sainz, A., Nicodemus, N., de Blas, C. and Carabano, R. (2008) Effect of dietary level and source of glutamine on intestinal health in the postweaning period. In: Xiccato, G., Trocino, A. and Lukefahr, S.D. (eds) Proceedings of the 9th World Rabbit Congress, Verona. Fondazione Iniziative Zooprofilattiche e Zootecniche, Brescia, Italy, pp. 529-534.

Bellier, R. and Gidenne, T. (1996) Consequences of reduced fibre intake on digestion, rate of passage and caecal microbial activity in the young rabbit. British Journal of Nutrition 75, 353-363.

Bennegadi, N., Gidenne, T. and Licois, L. (2001) Impact of fibre deficiency and sanitary status on nonspecific enteropathy of the growing rabbit. Animal Research 50, 401-413.

Bennegadi, N., Fonty, G., Millet, L., Gidenne, T. and Licois, D. (2003) Effects of age and dietary fibre level on caecal microbial communities of conventional and specific pathogen-free rabbits. Microbial Ecology in Health and Disease 15, 23-32. 
Bernardini, M., Dal Bosco, A., Castellini, C. and Miggiano, G. (1996) Dietary vitamin E supplement in rabbit: antioxidant capacity and meat quality. In: Lebas, F. (ed.) Proceedings of the 6th World Rabbit Congress, Toulouse, Vol. 3. Association Française de Cuniculture, Lempdes, France, pp. 137-140.

Blas, E. and Gidenne, T. (2010) Digestion of sugars and starch. In: de Blas, C. and Wiseman, J. (eds) The Nutrition of the Rabbit, 2nd edition. CAB International, Wallingford, UK, pp. 19-38.

Blas, E., Cervera, C. and Fernandez Carmona, J. (1994) Effect of two diets with varied starch and fibre levels on the performances of 4-7 weeks old rabbits. World Rabbit Science 2, 117-121.

Boisot, P., Licois, D. and Gidenne, T. (2003) Feed restriction reduces the sanitary impact of an experimental reproduction of epizootic rabbit enteropathy syndrome (ERE), in the growing rabbit. In: Bolet, G. (ed.) Proceedings of 10ème J. Rech. Cunicoles, 19-20 Nov., Paris, France. ITAVI Paris, France, pp. 267-270.

Cachaldora, P., Nicodemus, N., García, J., Carabaño, R. and de Blas, J.C. (2004) Efficacy of Amylofeed ${ }^{\circledR}$ in growing rabbit diets. World Rabbit Science 12, 23-31.

Carabaño, R., Villamide, M.J., Garcia, J., Nicodemus, N., Llorente, A., Chamorro, S., Menoyo, D., Garcia-Rebollar, P., Garcia-Ruiz, A.I. and De Blas, J.C. (2009) New concepts and objectives for protein-amino acid nutrition in rabbits: a review. World Rabbit Science 17, 1-14.

Carraro, L., Trocino, A., Fragkiadakis, M., Xiccato, G. and Radaelli, G. (2007) Digestible fibre to ADF ratio and starch level in diets for growing rabbits. Italian Journal of Animal Science 6(sup1), 752-754.

Catala, J. and Bonnafous, R. (1979) Modifications de la microflore quantitative, de l'excrétion fécale et du transit intestinal chez le lapin, après ligature du canal pancréatique. Annales de Zootechnie 28, 128.

Chamorro, S., Gomez Conde, M.S., Perez De Rozas, A.M., Badiola, I., Carabaño, R. and de Blas, J.C. (2007) Effect on digestion and performance of dietary protein content and increased substitution of lucerne hay with soya-bean protein concentrate in starter diets for young rabbits. Animal 1, 651-659.

Chamorro, S., de Blas, C., Grant, G., Badiola, I., Menoyo, D. and Carabano, R. (2010) Effect of dietary supplementation with glutamine and a combination of glutamine-arginine on intestinal health in twenty-five-day-old weaned rabbits. Journal of Animal Science 88, 170-180.

Clark, J.D., Jain, A.V., Hatch, R.C. and Mahaffey, E.A. (1980) Experimentally induced chronic aflatoxicosis in rabbits. American Journal of Veterinary Research 41, 1841-1845.

Clark, J.D., Jain, A.V. and Hatch, R.C. (1982) Effects of various treatments on induced chronic aflatoxicosis in rabbits. American Journal of Veterinary Research 4, 106-110.

Clark, J.D., Greene, C.E., Calpin, J.P., Hatch, R.C. and Jain, A.V. (1986) Induced aflatoxicosis in rabbits: blood coagulation defects. Toxicology and Applied Pharmacology 86, 353-361.

Combes, S., Fortun-Lamothe, L., Cauquil, L. and Gidenne, T. (2013) Engineering the rabbit digestive ecosystem to improve digestive health and efficacy. Animal 7, 1429-1439.

Čonková, E., Laciaková, A., Pástorová, B., Seidel, H. and Kovác, G. (2001) The effect of zearalenone on some enzymatic parameters in rabbits. Toxicology Letters 121, 145-149.

Cortez, S., Brandeburger, H., Greuel, E. and Sundrum, A. (1992) Investigations of the relationships between feed and health status on the intestinal flora of rabbits. Tierärztlische Umschau 47, 544-549.

Davidson, J. and Spreadbury, D. (1975) Nutrition of the New Zealand White rabbit. Proceedings of the Nutrition Society 34, 75-83.

de Blas, J.C., Pérez, E., Fraga, M.J., Rodriguez, M. and Galvez, J.F. (1981) Effect of diet on feed intake and growth of rabbits from weaning to slaughter at different ages and weights. Journal of Animal Science 52, 1225-1232.

de Blas, J.C., Taboada, E., Mateos, G.G., Nicodemus, N. and Méndez, J. (1995) Effect of substitution of starch for fiber and fat in isoenergetic diets on nutrient digestibility and reproductive performance of rabbits. Journal of Animal Science 73, 1131-1137.

Debray, L., Fortun-Lamothe, L. and Gidenne, T. (2002) Influence of low dietary starch/fibre ratio around weaning on intake behaviour, performance and health status of young and rabbit does. Animal Research 51, 63-75.

Delgado, R., Nicodemus, N., Abad-Guamán, R., Sastre, J., Menoyo, D., Carabaño, R. and García, J. (2018a) Effect of dietary soluble fibre and $n-6 / n-3$ fatty acid ratio on growth performance and nitrogen and energy retention efficiency in growing rabbits. Animal Feed Science and Technology 227, 84-94.

Delgado, R., Abad-Guamán, R., Nicodemus, N., Villamide, M.J., Ruíz-López, N., Carabaño, R., Menoyo, D., García, J. (2018b) Effect of level of soluble fiber and n-6/n-3 fatty acid ratio on performance of rabbit does and their litters. Journal of Animal Science 96, 1084-1100.

Delgado, R., Nicodemus, N., Abad-Guamán, R., Menoyo, D., García, J. and Carabaño, R. (2019) Effect of arginine and glutamine supplementation on performance, health and nitrogen and energy balance in growing rabbits. Animal Feed Science and Technology 247, 63-73. 
Dojanã, N., Costache, M. and Dinischiotu, A. (1998) The activity of some digestive enzymes in domestic rabbits before and after weaning. Animal Science 66, 501-507.

EGRAN (2001) Technical note: attempts to harmonise chemical analyses of feeds and faeces, for rabbit feed evaluation. World Rabbit Science 9, 57-64.

Falçao-e-Cunha, L., Castro-Solla, L., Maertens, L., Marounek, M., Pinheiro, V., Freire, J. and Mourao, J.L. (2007) Alternatives to antibiotic growth promoters in rabbit feeding: a review. World Rabbit Science 15,127-140.

Fekete, S. and Huszenicza, G. (1993) Effect of T-2 toxin on ovarian activity and some metabolic variables of rabbits. Laboratory Animal Science 43, 646-649.

Fekete, S., Tamas, J., Vanyi, A., Glavits, R. and Bata, A. (1989) Effect of T-2 toxin on feed intake, digestion and pathology of rabbits. Laboratory Animal Science 39, 603-606.

Fernandez-Carmona, J., Cervera, C. and Blas, E. (1996) High fat for rabbits breeding does housed at $30^{\circ} \mathrm{C}$. In: Lebas, F. (ed.) Proceedings of the 6th World Rabbit Congress, Toulouse, Vol. 1. Association Française de Cuniculture, Lempdes, France, pp. 167-169.

Fioramonti, J., Sorraing, J.M., Licois, D. and Bueno, L. (1981) Intestinal motor and transit disturbances associated with experimental coccidiosis (Eimeria magna) in the rabbit. Annales de Recherches Vétérinaires 12, 413-420.

Fortun-Lamothe, L. (2006) Energy balance and reproductive performance in rabbit does. Animal Reproduction Science 93, 1-15.

Fortun-Lamothe, L. and Boullier, S. (2007) A review on the interactions between gut microflora and digestive mucosal immunity. Possible ways to improve the health of rabbits. Livestock Science, 107, 1-18.

Fortun-Lamothe, L., Lacanal, L., Boisot, P., Jehl, N., Arveux, A., Hurtaud, J. and Perrin, G. (2005) Effects of level and origin of dietary energy on reproduction performance of the does and health status of the young. In: Bolet, G. (ed.) Proceedings of 11ème J. Rech. Cunicoles, 29 and 30 Nov. 2005, Paris. ITAVI, Paris, France, pp. 129-132.

Fraga, M.J., Lorente, M., Carabaño, R. and de Blas, J.C. (1989) Effect of diet and remating interval on milk production and milk composition of the doe rabbit. Animal Production 48, 459-466.

Gallois, M., Gidenne, T., Tasca, C., Caubet, C., Coudert, C., Milon, A. and Boullier, S. (2007) Maternal milk contains antimicrobial factors that protect young rabbits from enteropathogenic Escherichia coli infection. Clinical and Vaccine Immunology 14, 585-592.

Gallois, M., Gidenne, T., Orengo, J., Caubet, C., Tasca, C., Milon, A. and Boullier, S. (2008) Testing the efficacy of medium chain fatty acids against rabbit colibacillosis. Veterinary Microbiology 131, 192-198.

Galtier, P., Baradat, C. and Alvinerie, M. (1977) Etude de l'élimination d'ochratoxine A par le lait chez la lapine. Annales de la Nutrition et de l'Alimentation 31, 911-918.

García, J., Carabaño, R. and de Blas, C. (1999) Effect of fiber source on cell wall digestibility and rate of passage in rabbits. Journal of Animal Science 77, 898-905.

García, J., Carabano, R., Pérez-Alba, L. and de Blas, C. (2000) Effect of fiber source on cecal fermentation and nitrogen recycled through cecotrophy in rabbits. Journal of Animal Science 78, 638-646.

García, J., Gidenne, T., Falcão e Cunha, L. and de Blas, C. (2002) Identification of the main factors that influence caecal fermentation traits in growing rabbits. Animal Research 51, 165-173.

García-Ruiz, A.I., García-Palomares, J., García-Rebollar, P., Chamorro, S., Carabaño, R. and de Blas, C. (2006) Effect of protein source and enzyme supplementation on ileal protein digestibility and fattening performance in rabbits. Spanish Journal of Agricultural Research 4, 297-303.

Gentry, P.A. (1982) The effect of administration of a single dose of T-2 toxin on blood coagulation in the rabbit. Canadian Journal of Comparative Medicine 46, 414-419.

Gidenne, T. (1995) Effect of fibre level reduction and gluco-oligosaccharides addition on the growth performance and caecal fermentation in the growing rabbit. Animal Feed Science and Technology 56, $253-263$.

Gidenne, T. (1997) Caeco-colic digestion in the growing rabbit: impact of nutritional factors and related disturbances. Livestock Production Science 51, 73-88.

Gidenne, T. (2015) Dietary fibres in the nutrition of the growing rabbit and recommendations to preserve digestive health: a review. Animal 9, 227-242.

Gidenne, T. and Licois, D. (2005) Effect of a high fibre intake on the resistance of the growing rabbit to an experimental inoculation with an enteropathogenic strain of Escherichia coli. Animal Science 80, 281-288.

Gidenne, T., Carré, B., Segura, M., Lapanouse, A. and Gomez, J. (1991) Fibre digestion and rate of passage in the rabbit: effect of particle size and level of lucerne meal. Animal Feed Science and Technology 32, 215-221. 
Gidenne, T., Pinheiro, V. and Falcão e Cunha, L. (2000) A comprehensive approach of the rabbit digestion: consequences of a reduction in dietary fibre supply. Livestock Production Science 64, 225-237.

Gidenne, T., Arveux, P. and Madec, O. (2001a) The effect of the quality of dietary lignocellulose on digestion, zootechnical performance and health of the growing rabbit. Animal Science 73, 97-104.

Gidenne, T., Kerdiles, V., Jehl, N., Arveux, P., Briens, C., Eckenfelder, B., Fortune, H., Montessuy, S., Muraz, G. and Stephan, S. (2001b) An increase of dietary ratio 'digestible fibre/crude protein' does not affect the performances of the growing rabbit but reduce enteritis incidence: preliminary results of a multisite study. In: Bolet, G. (ed.) Proceedings of the 9th J. Rech. Cunicoles, 28 and 29 Nov., Paris. ITAVI, Paris, France, pp. 65-68.

Gidenne, T., Jehl, N., Segura, M. and Michalet-Doreau, B. (2002) Microbial activity in the caecum of the rabbit around weaning: impact of a dietary fibre deficiency and of intake level. Animal Feed Science and Technology 99, 107-118.

Gidenne, T., Jehl, N., Lapanouse, A. and Segura, M. (2004a) Inter-relationship of microbial activity, digestion and gut health in the rabbit: effect of substituting fibre by starch in diets having a high proportion of rapidly fermentable polysaccharides. British Journal of Nutrition 92, 95-104.

Gidenne, T., Mirabito, L., Jehl, N., Perez, J.M., Arveux, P., Bourdillon, A., Briens, C., Duperray, J. and Corrent, E. (2004b) Impact of replacing starch by digestible fibre, at two levels of lignocellulose, on digestion, growth and digestive health of the rabbit. Animal Science 78, 389-398.

Gidenne, T., Segura, M. and Lapanouse, A. (2005a) Effect of cereal sources and processing in diets for the growing rabbit. I. Effects on digestion and fermentative activity in the caecum. Animal Research 54, 55-64.

Gidenne, T., Jehl, N., Perez, J.M., Arveux, P., Bourdillon, A., Mousset, J.L., Duperray, J., Stephan, S. and Lamboley, B. (2005b) Effect of cereal sources and processing in diets for the growing rabbit. II. Effects on performances and mortality by enteropathy. Animal Research 54, 65-72.

Gidenne, T., Combes, S., Feugier, A., Jehl, N., Arveux, P., Boisot, P., Briens, C., Corrent, E., Fortune, H., Montessuy, S. and Verdelhan, S. (2009a) Feed restriction strategy in the growing rabbit. 2. Impact on digestive health, growth and carcass characteristics. Animal 3, 509-515.

Gidenne, T., Murr, S., Travel, A., Corrent, E., Foubert, C., Bebin, K., Mevel, L., Rebours, G. and Renouf, B. (2009b) Effets du niveau de rationnement et du mode de distribution de l'aliment sur les performances et les troubles digestifs post-sevrage du lapereau - premiers resultats d'une étude concertée du reseau GEC. Cuniculture Magazine 36, 65-72.

Gidenne, T., Combes, S. and Fortun-Lamothe, L. (2012) Feed intake limitation strategies for the growing rabbit: effect on feeding behaviour, welfare, performance, digestive physiology and health: a review. Animal 6, 1407-1419.

Gidenne, T., Kerdiles, V., Jehl, N., Arveux, P., Eckenfelder, B., Briens, C., Stephan, S., Fortune, H., Montessuy, S. and Muraz, G. (2013) Protein replacement by digestible fibre in the diet of growing rabbits. 2-Impact on performances, digestive health and nitrogen output. Animal Feed Science and Technology $183,142-150$.

Gómez-Conde, M.S., García, J., Chamorro, S., Eiras, P., Rebollar, P.G., Pérez de Rozas, A., Badiola, I., de Blas, C. and Carabaño, R. (2007) Neutral detergent-soluble fibre improves gut barrier function in 25 d old weaned rabbits. Journal of Animal Science 85, 3313-3321.

Gómez-Conde, M.S., Pérez de Rozas, A., Badiola, I., Pérez-Alba, L., de Blas, J.C., Carabaño, R. and García, J. (2009) Effect of neutral detergent soluble fibre on digestion, intestinal microbiota and performance in twenty five day old weaned rabbits. Livestock Science 125, 192-198.

Guimarães, C.S. and Motta, F.W. (2000) Bioavailibility of dietary zinc sources for fattening rabbits. In: Blasco A. (ed.) Proceedings of the 7th World Rabbit Congress, Valencia, Vol. 3. Valencia University Publications, Valencia, Spain, pp. 255-261.

Gutiérrez, I., García, P., Carabaño, R. and de Blas, J.C. (2000) Effect of suplementation with animal plasma and antibiotics on jejunal morphology of early-weaned rabbits. World Rabbit Science 8, 263-267.

Gutiérrez, I., Espinosa, A., García, J., Carabano, R. and de Blas, J.C. (2002a) Effect of levels of starch, fiber, and lactose on digestion and growth performance of early-weaned rabbits. Journal of Animal Science 80, 1029-1037.

Gutiérrez, I., Espinosa, A., García, J., Carabano, R. and de Blas, J.C. (2002b) Effects of starch and protein sources, heat processing, and exogenous enzymes in starter diets for early weaned rabbits. Animal Feed Science and Technology 98, 175-186.

Gutiérrez, I., Espinosa, A., García, J., Carabano, R. and de Blas, C. (2003) Effect of protein source on digestion and growth performance of early-weaned rabbits. Animal Research 52, 461-471.

Habeeb, A.A.M., Marai, I.F.M., El-Maghawry, A.M. and Gad, A.E. (1997) Physiological response of growing rabbit to different concentrations of salinity in drinking water under winter and hot summer conditions. Egyptian Journal of Rabbit Science 7, 81-94. 
Haffar, A., Laval, A. and Guillou, J.P. (1988) Entérotoxémie à Clostridium spiroforme chez des lapins adultes. Le Point Vétérinaire 20, 99-102.

Hall, M.B., Lewis, B.A., Van Soest, P.J. and Chase, L.E. (1997) A simple method for estimation of neutral detergent-soluble fibre. Journal of the Science of Food and Agriculture 74, 441-449.

Hanika, C., Carlton, W.W. and Tuite, J. (1983) Citrinin mycotoxicosis in the rabbit. Food and Chemical Toxicology 21, 487-496.

Hanika, C., Carlton, W.W., Boon, G.D. and Tuite, J. (1984) Citrinin mycotoxicosis in the rabbit: clinicopathological alterations. Food and Chemical Toxicology 22, 999-1008.

Hodgson, J. (1974) Diverticular disease. Possible correlation between low residue diet and raised intracoIonic pressures in the rabbit model. American Journal of Gastroenterology 62, 116-123.

Kammerer, M. and Pinault, L. (1998) Pollution de l'eau d'abreuvement par les nitrates. Tolérance générale et influence sur la croissance pondérale chez le lapin. 7e Journées de la Recherche Cunicole en France, Lyon. ITAVI, Paris, France, pp. 191-197.

Khera, K.S., Whalen, C. and Angers, G. (1986) A teratology study on vomitoxin (4-deoxynivalenol) in rabbits. Food and Chemical Toxicology 24, 421-424.

Kjaer, K.B. and Jensen, J.A. (1997) Perirenal fat, carcass conformation, gain and feed efficiency of growing rabbits as affected by dietary protein and energy content. World Rabbit Science 5, 93-97.

Knudsen, C., Combes, S., Briens, C., Coutelet, G., Duperray, J., Rebours, G., Salaün, J.M., Travel, A., Weissman, D. and Gidenne, T. (2017) Substituting starch with digestible fiber does not impact on health status or growth in restricted fed rabbits. Animal Feed Science and Technology 226, 152-161.

Krishna, L., Dawra, R.K., Vaid, J. and Gupta, V.K. (1991) An outbreak of aflatoxicosis in Angora rabbits. Veterinary and Human Toxicology 33, 159-161.

Laplace, J.P. and Lebas, F. (1977) Le transit digestif chez le lapin. 7) Influence de la finesse de broyage des constituants d'un aliment granulé. Annales de Zootechnie 26, 413-420.

Lebas, F. (1973) Effet de la teneur en proteines de rations à base de soja ou de sésame sur la croisssance du lapin. Annales de Zootechnie 22, 83-92.

Lebas, F. (2018) Performances moyennes des élevages cunicoles en France, pour l'année 2017. Résultats RENACEB. Cuniculture Magazine 45, 22-36.

Lebas, F. and Fortun-Lamothe, L. (1996) Effects of dietary energy level and origin (starch vs oil) on performance of rabbit does and their litters: average situation after 4 weanlings. In: Lebas, F. (ed.) Proceedings of the 6th World Rabbit Congress, Toulouse, Vol. 1. Association Française de Cuniculture, Lempdes, France, pp. 217-222.

Lebas, F. and Lamboley, B. (1999) Méthode de détermination par tamisage en phase liquide de la taille des particules contenues dans un aliment granulé pour lapins. World Rabbit Science 7, 229-235.

Lebas, F., Maître, I., Seroux, M. and Franck, T. (1986) Influence du broyage des matières premières avant agglomération de 2 aliments pour lapins différant par leur taux de constituants membranaires: digestibilité et performances de croissance. In: Proceedings of the 4th J. Rech. Cunicole Fr., Paris, Vol. 1. ITAVI. Paris, France, pp. 9.1-9.13.

Lebas, F., Coudert, P., De Rochambeau, H. and Thébault, R.G. (1996) Le Lapin Elevage et Pathologie. FAO, Rome, Italy.

Licois D. (2004) Domestic rabbit enteropathies. In: Becerril, C. and Pro, A. (eds) 8th World Rabbit Congress, 7-10 September, Puebla, Mexico, pp. 385-403.

Maertens, L. (1999) Towards reduced feeding costs, dietary safety and minimal mineral excretion in rabbits: a review. World Rabbit Science 7, 65-74.

Maertens, L. and Struklec, M. (2006) Technical note: preliminary results with a tannin extract on the performance and mortality of growing rabbits in an enteropathy infected environment. World Rabbit Science 14, 189-192.

Maertens, L., Perez, J.M., Villamide, M., Cervera, C., Gidenne, T. and Xiccato, G. (2002) Nutritive value of raw materials for rabbits: EGRAN Tables 2002. World Rabbit Science 10, 157-166.

Maertens, L., Aerts, J.M. and De Boever, J. (2004) Degradation of dietary oligofructose and inulin in the gastro-intestinal tract of the rabbit and the effects on caecal $\mathrm{pH}$ and volatile fatty acids. World Rabbit Science 12, 235-246.

Maertens, L., Aerts, J.M. and De Brabander, D.L. (2005) Effect of a diet rich in n-3 fatty acids on the performances and milk composition of does and the viability of their progeny. In: Bolet, G. (ed.) Proc. 11ème J. Rech. Cunicoles. ITAVI, Paris, France pp. 205-208.

Maertens, L., Falcao E Cunha, L. and Marounek, M. (2006) Feed additives to reduce the use of antibiotics. In: Coudert, L.M.a.P. (ed.) Recent advances in rabbit sciences. COST (ESF) and ILVO, Melle, Belgium pp. 259-265. Available from: http://world-rabbit-science.com/Documents/Cost848.pdf (accessed 24 August 2019). 
Maître, I., Lebas, F., Arveux, P., Bourdillon, A., Duperray, J. and Saint Cast, Y. (1990) Taux de lignocellulose (ADF de Van-Soest) et performances de croissance du lapin de chair. In: Lebas, F. (ed.) 5ème J. Rech. Cunicoles Fr., ITAVI, Paris, France, pp. 56.1-56.11.

Martinez-Paredes, E., Rodenas, L., Pascual, J.J., Blas, E., Brecchia, G., Boiti, C. and Cervera, C. (2015) Effects of rearing feeding programme on the young rabbit females' behaviour and welfare indicators. World Rabbit Science 23, 197-205.

Mézes, M. and Balogh, K. (2010) Mycotoxins in rabbit feed: a review. World Rabbit Science 17, 53-62.

Montagne, L., Pluske, J.R. and Hampson, D.J. (2003) A review of interactions between dietary fibre and the intestinal mucosa, and their consequences on digestive health in young non-ruminant animals. Animal Feed Science and Technology 108, 95-117.

Morisse, J.P., Wyers, M. and Drouin, P. (1981) Aflatoxicose chronique chez le lapin. Essai de reproduction expérimentale. Recueil de Médecine Vétérinaire de l'Ecole d'Alfort 157, 363-368.

Morisse, J.P., Boilletot, E. and Maurice, R. (1989) Incidence des nitrites chez les lapins. Cuniculture 16, 197-199.

Mourao, J.L., Pinheiro, V., Alves, A., Guedes, C.M., Pinto, L., Saavedra, M.J., Spring, P. and Kocher, A. (2006) Effect of mannan oligosaccharides on the performance, intestinal morphology and caecal fermentation of fattening rabbits. Animal Feed Science and Technology 126, 107-120.

Newberne, P.M. and Butler, W.H. (1969) Acute and chronic effects of aflatoxin on the liver of domestic and laboratory animals: a review. Cancer Research 29, 236-250.

Nicodemus, N., Carabaño, R., García, J., Mendez, J. and de Blas, J.C. (1999) Performance response of lactating and growing rabbits to dietary lignin content. Animal Feed Science and Technology 80, 43-54.

Nicodemus, N., García, J., Carabaño, R. and de Blas, J.C. (2006) Effect of a reduction of dietary particle size by substituting a mixture of fibrous by-products for lucerne hay on performance and digestion of growing rabbits and lactating does. Livestock Science 100, 242-250.

Nicodemus, N., Redondo, R., Pérez-Alba, L., Carabaño, R., De Blas, J.C. and García, J. (2010) Effect of level of fibre and type of grinding on the performance of rabbit does and their litters during the first three lactations. Livestock Science 129, 186-193.

Ocasio-Vega, C., Delgado, R., Abad-Guamán, R., Carabaño, R., Carro, M.D., Menoyo, D. and García, J. (2018) The effect of cellobiose on the health status of growing rabbits depends on the dietary level of soluble fibre. Journal of Animal Science 96, 1806-1817.

Ocasio-Vega, C., Delgado, R., Abad-Guamán, R., Carabaño, R., Carro, M.D. and García, J. (2019) Effect of cellobiose supplementation on growth performance and health in rabbits. Livestock Science 221, 163-171.

Osborn, R.G., Osweiler, G.D. and Foley, C.W. (1988) Effects of zearalenone on various components of rabbit uterine tubal fluid. American Journal of Veterinary Research 49, 1382-1386.

Perez, J.M. and Leuillet, M. (1986) Composition et valeur nutritive des céréales. Perspectives Agricoles $105,56-61$.

Perez, J.M., Gidenne, T., Lebas, F., Caudron, I., Arveux, P., Bourdillon, A., Duperray, J. and Messager, B. (1994) Apports de lignines et alimentation du lapin en croissance. II. Conséquences sur les performances de croissance et la mortalité. Annales de Zootechnie 43, 323-332.

Perez, J.M., Gidenne, T., Bouvarel, I., Caudron, I., Arveux, P., Bourdillon, A., Briens, C., Le Naour, J., Messager, B. and Mirabito, L. (1996) Apports de cellulose dans l'alimentation du lapin en croissance. II. Conséquences sur les performances et la mortalité. Annales de Zootechnie 45, 299-309.

Perez, J.M., Gidenne, T., Bouvarel, I., Arveux, P., Bourdillon, A., Briens, C., Le Naour, J., Messager, B. and Mirabito, L. (2000) Replacement of digestible fibre by starch in the diet of the growing rabbit. II. Effects on performances and mortality by diarrhoea. Annales de Zootechnie 49, 369-377.

Pompa, G., Montesissa, C., Di Lauro, F.M. and Fadini, L. (1986) The metabolism of zearalenone in subcellular fractions from rabbit and hen hepatocytes and its estrogenic activity in rabbits. Toxicology 42, 69-75.

Porter, L.P., Borgman, R.F. and Lightsey, S.F. (1988) Effect of water hardness upon lipid and mineral metabolism in rabbits. Nutrition Research 8, 31-45.

Prohaszka, L. (1980) Antibacterial effect of volatile fatty acids in enteric E. coli infections of rabbits. Zentralblatt Veterinar Medecine B 27, 631-639.

Rémois, G. and Rouillère, H. (1998) Effet du sulfate d'aluminium sur les performances des lapins d'engraissement. 7e Journées de la Recherche Cunicole en France, Lyon. ITAVI, Paris, France, pp. 195-197.

Romero, C., Cuesta, S., Astillero, J.R., Nicodemus, N. and de Blas, C. (2010) Effect of early feed restriction on performance and health status in growing rabbits slaughtered at $2 \mathrm{~kg}$ live-weight. World Rabbit Science 18, 211-218.

Scheele, C.W. and Bolder, N.M. (1987) Health problems and mortality of young suckling rabbits in relation to dietary composition. In: Rabbit Production Systems Including Welfare. Commision of the European Communities, Brussels, Belgium, pp. 115-125. 
Skrivanova, V. and Marounek, M. (2006) A note on the effect of triacylglycerols of caprylic and capric fatty acid on performance, mortality, and digestibility of nutrients in young rabbits. Animal Feed Science and Technology 127, 161-168.

Skrivanova, E., Molatova, Z. and Marounek, M. (2008) Effects of caprylic acid and triacylglycerols of both caprylic and capric acid in rabbits experimentally infected with enteropathogenic Escherichia coli O103. Veterinary Microbiology 126, 372-376.

Skrivanova, E., Molatova, Z., Skrivanova, V. and Marounek, M. (2009) Inhibitory activity of rabbit milk and medium-chain fatty acids against enteropathogenic Escherichia coli O128. Veterinary Microbiology 135, 358-362.

Soler, M., Blas, E., Cano, J., Pascual, J.J., Cervera, C. and Fernandez-Carmona, J. (2004) Effect of digestible fibre / starch ratio and animal fat level in diets around weaning on mortality rate of rabbits. In: Becerril, C. and Pro, A. (eds) 8th World Rabbit Congress. Colegio de Postgraduados for WRSA, Puebla, Mexico, pp. 996-1001.

Tazzoli, M., Carraro, L., Trocino, A., Majolini, D. and Xiccato, G. (2009) Replacing starch with digestible fibre in growing rabbit feeding. Italian Journal of Animal Science 8, 148-150.

Tazzoli, M., Xiccato, G., Trocino, A., Majolini, D., El Abed, N., García, J., Eras, M.A. and Carabaño, R. (2012) Dietary supplementation with mannanoligosaccharides and $\beta$ glucans in growing rabbits. 1. growth performance, health status and carcass traits. In: E.R.S.A. (ed.) 10th World Rabbit Congress, Sharm El Sheik, Egypt, pp. 547-551.

Tazzoli, M., Birolo, M., Filiou, E., Trocino, A., Zuffellato, A. and Xiccato G. (2013) Increasing dietary energy with starch and soluble fibre and reducing ADF at different protein levels for growing rabbits. Agriculturae Conspectus Scientificus 78, 235-239.

Trocino, A., Fragkiadakis, M., Radaelli, G. and Xiccato, G. (2010) Effect of dietary soluble fibre level and protein source on growth, digestion, caecal activity and health of fattening rabbits. World Rabbit Science 18, 199-210.

Trocino, A., Fragkiadakis, M., Majolini, D., Carabaño, R. and Xiccato, G. (2011) Effect of the increase of dietary starch and soluble fibre on digestive efficiency and growth performance of meat rabbits. Animal Feed Science and Technology 165, 265-277.

Trocino, A., Garcia, J., Carabaño, R. and Xiccato, G. (2013) A meta-analysis of the role of soluble fibre in diets for growing rabbits. World Rabbit Science 21, 1-15.

Vanyi, A., Glavits, R., Bata, A., Fekete, S. and Tamas, J. (1989) The pathological effects, metabolism and excretion of T-2 toxin in rabbits. Journal of Applied Rabbit Research 12, 194-200.

Virag, Gy., Eiben, Cs., Tóth, T. and Schmidt, J. (2008) Colour and pH of rabbit meat and fat deposits as affected by the source and dose of dietary vitamin E supplementation. In: Xiccato, G., Trocino, A. and Lukefahr, S.D. (eds) Proceedings of the 9th World Rabbit Congress, Verona. Fondazione Iniziative Zooprofilattiche e Zootecniche, Brescia, Italy, pp. 1467-1471.

Volek, Z. and Marounek, M. (2011) Dried chicory root (Cichorium intybus L.) as a natural fructan source in rabbit diet: effects on growth performance, digestion and caecal and carcass traits. World Rabbit Science 19, 143-150.

Volek, Z., Marounek, M. and Skrivanova, V. (2005) Replacing starch by pectin and inulin in diet of earlyweaned rabbits: effect on performance, health and nutrient digestibility. Journal of Animal and Feed Sciences 14, 327-337.

Volek, Z., Marounek, M. and Skrivanova, V. (2007) Effect of a starter diet supplementation with mannanoligosaccharide or inulin on health status, caecal metabolism, digestibility of nutrients and growth of early weaned rabbits. Animal 1, 523-530.

Xiccato, G., Trocino, A., Carraro, L. and Fragkiadakis, M. (2006) Digestible fibre to adf ratio and protein concentration in diets for early-weaned rabbits. In: Scapinello, C. (ed.) 3rd Rabbit congress of the Americas. Maringa University, Maringa, Parana state, Brasil, pp. 1-6.

Xiccato, G., Trocino, A., Carraro, L., Fragkiadakis, M. and Majolini, D. (2008) Digestible fibre to starch ratio and antibiotic treatment time in growing rabbits affected by epizootic rabbit enteropathy. In: Xiccato, G. and Lukefahr, S.D. (eds), 9th World Rabbit Congress. Fond. Ini. Zooprofilattiche e Zoot. publ. Brescia Italy, Verona, Italy, pp. 847-851.

Xiccato, G., Trocino, A., Majolini, D., Fragkiadakis, M. and Tazzoli, M. (2011) Effect of decreasing dietary protein level and replacing starch with soluble fibre on digestive physiology and performance of growing rabbits. Animal 5, 1179-1187.

Xiccato, G., Trocino, A., Tazzoli, M., Majolini, D., Carabaño, R., Villamide, M.J., García, J., Nicodemus, N., Abad, R., Blas, E., Cervera, C., Ródenas, L., Martínez, E., Falcao-E-Cunha, L., Bengala Freire, J.P., Maertens, L., Bannelier, C., Segura, M. and Gidenne, T. (2012) European ring-test on the chemical analyses of total dietary fibre and soluble fibre of compound diets and raw materials for rabbits. Proceedings of the 10th World Rabbit Congress. Sharm El-Sheikh, Egypt, pp. 453-471. 